\title{
Human iPSC-Derived Neural Models for Studying Alzheimer's Disease: from Neural Stem Cells to Cerebral Organoids
}

\author{
Martin Barak ${ }^{1}$. Veronika Fedorova ${ }^{1}$. Veronika Pospisilova ${ }^{1} \cdot$ Jan Raska $^{1} \cdot$ Simona Vochyanova $^{1} \cdot$ Jiri Sedmik $^{1,2}$. \\ Hana Hribkova ${ }^{1} \cdot$ Hana Klimova $^{1} \cdot$ Tereza Vanova $^{1,2}$ - Dasa Bohaciakova ${ }^{1,2}$
}

Accepted: 28 August 2021 / Published online: 2 February 2022

(c) The Author(s) 2021

\begin{abstract}
During the past two decades, induced pluripotent stem cells (iPSCs) have been widely used to study mechanisms of human neural development, disease modeling, and drug discovery in vitro. Especially in the field of Alzheimer's disease (AD), where this treatment is lacking, tremendous effort has been put into the investigation of molecular mechanisms behind this disease using induced pluripotent stem cell-based models. Numerous of these studies have found either novel regulatory mechanisms that could be exploited to develop relevant drugs for $\mathrm{AD}$ treatment or have already tested small molecules on in vitro cultures, directly demonstrating their effect on amelioration of AD-associated pathology. This review thus summarizes currently used differentiation strategies of induced pluripotent stem cells towards neuronal and glial cell types and cerebral organoids and their utilization in modeling $\mathrm{AD}$ and potential drug discovery.
\end{abstract}

Keywords iPSCs $\cdot$ Neural differentiation $\cdot$ Alzheimer's disease $\cdot$ In vitro differentiation $\cdot$ Neural stem cells $\cdot$ Neural progenitors $\cdot$ Neurons $\cdot$ Astrocytes $\cdot$ Microglia $\cdot$ Cerebral organoids

\section{Introduction}

Since their discovery, pluripotent stem cells and their differentiated progeny served as models for studying mechanisms of human neural development in vitro. Since the advent of induced pluripotent stem cell (iPSC) technology and CRISPR/Cas9 gene editing, they have become an excellent and unique tool to not only model human CNS-related diseases in the dish but also served as a resource for the drug discovery effort. This is an especially relevant feature for the field of Alzheimer's disease $(\mathrm{AD})$, where this treatment remains unavailable. Notably, over

Martin Barak and Veronika Fedorova contributed equally to this work.

This article belongs to the Topical Collection: Special issue on Neurogenesis and Neurodegeneration: Basic Research and Clinic Applications Guest Editor: Henning Ulrich

\footnotetext{
Dasa Bohaciakova

bohaciakova@med.muni.cz

1 Department of Histology and Embryology, Faculty of Medicine, Masaryk University Brno, Brno, Czech Republic

2 International Clinical Research Center, St. Anne's Faculty Hospital Brno, Brno, Czech Republic
}

60 studies have thus far been published that used iPSC-derived neural models to study $\mathrm{AD}$ in vitro. This review summarizes these studies and provides a unique view of AD-iPSC-based studies from the "differentiated cell type" perspective. Specifically, we provide a comprehensive summary of currently used approaches of differentiation of iPSCs to neural stem cells, neurons, glia, and organoids, including direct transdifferentiation approaches. At the same time, we summarize in vitro iPSCbased studies performed thus far on $\mathrm{AD}$ and highlight their key findings. Additionally, our review also contains a comprehensive table where all studies are listed based on the cell type, the type of mutation studied, and the main outcomes of the study. It could thus be used as a useful resource for researchers studying AD.

\section{Current Neurodifferentiation Strategies}

The development of the central nervous system in vivo is governed by a tightly regulated balance between neural stem/progenitor/precursor cell (NPC) proliferation and differentiation towards mature cell types (reviewed in [1, 2]). During early embryonic development in vivo (for details on the concept of neural induction, see BOX 1), the neural tube forms via primary and secondary neurulation (reviewed in 
[3]). During primary neurulation, a process via which the neural tube is formed in the head and trunk regions of the body, ectoderm becomes sequentially specified to give rise to the epidermis, the neural plate (neuro-ectoderm), and the neural tube. During the secondary neurulation, which occurs specifically in the caudal region in all vertebrates, including humans, condensed mesoderm directly transitions to (neuro)epithelium and forms a neural tube. Irrespectively of the means of differentiation, the neural tube is, at this stage, composed of multipotent NPCs, which further in the development become more restricted. With respect to their potency to generate neurons, astrocytes, or oligodendrocytes, they are referred to as "neuronal ", "astrocyte ", and "oligodendrocyte " precursors, respectively. Importantly, in vitro isolation and propagation of NPCs from the developing and adult rodent CNS has provided an essential tool to study the biology of NPCs and lineage differentiation potential (rat models reviewed in [4, 5], mouse models reviewed in [6]). Additionally, it also served as a basis for the induction of neural differentiation from pluripotent ES cells.

Currently, numerous differentiation protocols exist for the differentiation of neural cell types from human iPSCs, and these methods are comprehensively summarized in Fig. 1. They employ several strategies, which usually aim to mimic the in vivo developmental steps: the formation of the neuroepithelium, specialization of neural stem cells, which further differentiate towards neural progenitors and more mature cell types. The differentiation is usually achieved via the combination of specific cell culture media, growth factors, and small molecule inhibitors sequentially added to the culture media. Additionally, there are also differentiation protocols that are based on inducible overexpression of specific transcription factors that direct the differentiation towards a specific cell type. These are becoming increasingly common as they generate a relatively uniform population of the differentiated cell type of interest. Additionally, all in vitro strategies can also be divided into 2D and 3D methods, where 2D generate relatively simple and easy to characterize cell populations. On the other hand, 3D differentiation models are more functionally complex and more adequately mimic the developmental processes [7]. In the following chapters, we will summarize the necessary steps that are followed in each differentiation strategy. A special chapter is also dedicated to direct transdifferentiation strategies that might be especially important to consider when mimicking neurodegenerative diseases in vitro.
BOX 1: Concept of neural induction in vivo

In the developing embryo, cell fate determination represents the ultimate decision to initialize the formation of a specific structure. The pivotal experiments studying the onset of the nervous system development were carried out by Spemann and Mangold in amphibian embryos nearly 100 years ago. In their work, they introduced a concept of induction, which shows that the developing ectoderm relies on mesodermal signals to induce neurulation [8]. The mediators of the induction were studied by Saxén and Toivonen, who defined two gradients of "neuralizing" and "mesodermalizing substances" in the inductor tissue that influence the formation of the neural tube [9]. Later on, molecules NOGGIN, FOLLISTATIN, and CHORDIN were identified to play a role during neurulation [10-12]. The follow-up studies indicated that the function of these molecules lies in the inhibition of the bone morphogenic protein (BMP) signaling pathway and the suppression of BMP was found to be the key primary step in the neural-fate acquisition of the early ectoderm (reviewed in [13])

\section{Differentiation of Pluripotent Stem Cells Towards Neuroectoderm and Neural Stem Cells}

Early methods to direct the differentiation of iPSCs to neural fates used less defined approaches than currently used protocols. Treatment of human embryonic stem cells with retinoic acidRA [14], sequential culture in serum and serum-free media [15], or co-culture with specific stromal cell lines such as PA6 [16] were commonly used techniques to gain a population of NPCs. These NPCs were further maintained under conditions optimized for adult neural progenitors, such as three-dimensional spheroids (neurospheres) in the presence of Fibroblast growth factor 2 (FGF2) and Epidermal growth factor (EGF). All these approaches eventually led to the formation of cells with neural phenotype. However, the population of cells was always heterogeneous, conditions undefined, and the production of NPCs inefficient and time-consuming. In contrast, new approaches were designed to make the process of neural differentiation well defined, robust, and possibly exploitable by regenerative medicine in the future [17-20].

The initiation of neural differentiation in iPSCs leads to a series of morphogenic events resulting in the formation of radially organized cellular structures called neural rosettes [18, 21-23]. These structures are regarded as an early stage of neural development in vitro. Resembling the neural tube, neural rosettes function as a reservoir of NSCs. At this stage, NSCs can be isolated and further propagated in vitro without losing their characteristics. They can also be directed to differentiate into both neuronal and glial cell types [18]. Their constancy in differentiation potential and self-renewing capacity during in vitro cultivation has been evaluated in depth [19, 24]. 


\begin{tabular}{|c|c|c|}
\hline \multirow{2}{*}{ NSCs/NPCs } & $\begin{array}{l}\cdot \text { iPSCs } \rightarrow \text { RA } \rightarrow \text { culture in serum/serum-free media or co-culture with stromal cells } \rightarrow \text { NPCs in 3D + FGF2, EGF } \\
\cdot \text { iPSCs } \rightarrow \text { SMAD signaling inhibition } \rightarrow \text { EB formation } \rightarrow F G F 2 \rightarrow \text { NSCs isolation from neural rosettes by selective enzyme/FACS/manually }\end{array}$ & \begin{tabular}{|c|}
{$[16][17][18]$} \\
$[14]][18][20][21][25][27][28]$
\end{tabular} \\
\hline & $\begin{array}{l}- \text { Reprogramming into iNSC } \\
\text { - somatic cells } \rightarrow \text { expression of OSKM or ASCL1, NGN2, HES1, ID1, PAX6, BRN2, SOX2, C-MYC, KLF4 or SOX2, FOXG1, BRN2 or SOX2 } \\
- \text { - PBMCs } \rightarrow \text { expression of OSKM combined with culture media containing N2B27, SB431542, CHIR99021, VPA, Forskolin }\end{array}$ & $\begin{array}{c}\text { [29][31][32][33] } \\
{[35]}\end{array}$ \\
\hline \multirow[t]{3}{*}{ Neurons } & $\begin{array}{l}\text { - Isolated neural rosettes or NSCs/NPCs } \rightarrow \text { w/o FGF2 or EGF (can be modified by BDNF, GDNF, CAMP, Forskolin, or RA; additionally add } \\
\text { SMAD inhibitors with SHH and WNT signaling activators in the case of forebrain dopamine neurons) }\end{array}$ & {$[18][20][23][44][45][46]$} \\
\hline & $\begin{aligned} \cdot \text { Reprogramming - iPSCs } & \rightarrow \text { BRN2, ASCL1, and MYT1L or NGN2 } \rightarrow \text { iNs } \\
& \rightarrow \text { ASCL and DLX2 } \rightarrow \text { GABAergic iNs } \\
& \rightarrow \text { NGN2 }+ \text { inhibition of SMAD and SHH } \rightarrow \text { glutamatergic iNs } \\
& \rightarrow \text { NGN2 (doxycycline-inducible promoter) } \rightarrow \text { i3Ns }\end{aligned}$ & $\begin{array}{c}{[50][51]} \\
{[52][53]} \\
{[54]} \\
{[55]}\end{array}$ \\
\hline & $\begin{array}{r}\text { Transdifferentiation - fibroblasts, hepatocytes } \rightarrow \text { BRN2, ASCL1, MYT1L, and NEUROD1 } \rightarrow \text { iNs } \\
- \text { fibroblasts } \rightarrow \text { miRNAs and trancription factors } \rightarrow \text { different types of iNs }\end{array}$ & $\begin{array}{c}{[50][136]} \\
{[121][137][138][139]}\end{array}$ \\
\hline & $\begin{array}{l}\cdot \text { NSCs, NPCs } \rightarrow \text { CNTF, BMP, FGF2, FBS or no growth factors, FBS or CNTF, LIF or B27, CNTF } \\
\cdot \text { - OPCs, NPCs } \rightarrow \text { N2, B27-RA, BMP4, FGF2 } \\
\cdot \text { Reprogramming - iPSCs } \rightarrow \text { expression of NFIA/NFIA and SOX9 } \rightarrow \text { iA }\end{array}$ & $\begin{array}{c}{[66][67][68][69]} \\
{[71]} \\
{[59][60][62]}\end{array}$ \\
\hline Oligode & $\begin{array}{l}\cdot \text { iPSCs } \rightarrow \text { neurosphere formation } \rightarrow \text { "glial restriction medium" } \rightarrow \text { manual selection of OPCS } \\
\cdot \text { hESCs } \rightarrow \text { RA } \rightarrow \text { inhibition of SMAD signaling by Noggin } \\
\cdot \text {. iPSCs } \rightarrow \text { IGF-I, NT-3, CAMP or IGF-I, PDGF, T3, butyryl cAMP or CNTF, EGF, FGF2, IGF-I, PDGF-AA, T3, AA or PDGF-AA, IGF-I, NT-3, BDNF } \\
\cdot \text {-3D cortical spheroids } \rightarrow \text { IGF-I with ketoconazole and clemastine } \\
\cdot \text { Reprogramming - iPSCS, NPCs } \rightarrow \text { expression soX10 and OLIG2 or SOX10 alone }\end{array}$ & $\begin{array}{c}{[98]} \\
{[99]} \\
{[100][101][102][103][104]} \\
{[90]} \\
{[52][105][106][107][108][93}\end{array}$ \\
\hline & $\begin{aligned} \cdot & \text { iPSCs } \rightarrow \text { EBs in medium }(\text { CSF1, IL-34) } \rightarrow \text { yolk sac EBs } \rightarrow \text { microglia-like precursor cells } \rightarrow \text { microglia-like cells } \\
\cdot & \text { iPSCs } \rightarrow \text { BMP4, VEGF, SCF } \rightarrow \text { EBs } \rightarrow \text { M-CSF, IL-3 } \rightarrow \text { embryonic macrophage precursors } \rightarrow \text { co-culture with cortical neurons, IL-34, GM-CSF } \\
\cdot \text { : iPSCs } & \rightarrow \text { BMP4 } \rightarrow \text { FGF2, SCF, VEGFA } \rightarrow \text { SCF, IL-3, TPO, M-CSF, FLT3 } \rightarrow \text { M-CSF, FLT3, GM-CSF } \rightarrow \text { IL-34, GM-CSF } \\
& \rightarrow \text { iHPCs } \rightarrow \text { ITS-G, B27, N2, insulin } \rightarrow \text { M-CSF, IL-34, TGFB-1 (after 35d add CD200 and CX3CL1) } \\
& \rightarrow \text { co-culture with astrocytes or neurons }\end{aligned}$ & $\begin{array}{l}{[111]} \\
{[113]} \\
{[115]} \\
{[114]} \\
{[116][117]}\end{array}$ \\
\hline $\begin{array}{l}\text { Cerebral } \\
\text { organoids }\end{array}$ & $\begin{array}{l}\cdot \text {-iPSCs } \rightarrow \text { EBS } \rightarrow \text { N2, heparin } \rightarrow \text { N2, B27, insulin, vitamin A } \rightarrow \text { media with RA and w/o B27, vitamin A } \rightarrow \text { whole-brain organoids } \\
\cdot \text { iPSCs } \rightarrow \text { SMAD inhibition } \rightarrow \text { FGF2, EGF } \rightarrow \text { BDNF, NT3 } \rightarrow \text { cortical spheroids } \\
\cdot-h E S C s \rightarrow \text { FGF2, SB431542 } \rightarrow \text { FGF19 } \rightarrow \text { SDF1 } \rightarrow \text { cerebellar organoids } \\
\cdot-h E S C s \rightarrow \text { SB431542, IWR1e } \rightarrow \text { add CHIR, BMP4, FBS } \rightarrow \text { hippocampal organoids } \\
\cdot \cdot \text { iPSCs } \rightarrow \text { SB431542, Noggin, CHIR99021 } \rightarrow \text { EBS } \rightarrow \text { SHH-C25II, FGF8 } \rightarrow \text { BDNF, GDNF, ascorbic acid, db-CAMP } \rightarrow \text { midbrain organoids }\end{array}$ & $\begin{array}{l}{[142]} \\
{[145]} \\
{[146]} \\
{[147]} \\
{[148]}\end{array}$ \\
\hline
\end{tabular}

Fig. 1 Differentiation protocols. Summary of neurodifferentiation strategies to generate specific cell types of the central nervous system from stem cells. For each strategy, we list major growth factors, small molecules, and other reagents that must be added to the cell culture

The majority of protocols that have been established to generate NSCs rely on the formation of neural rosettes as a source of NSCs [17-20, 25, 26]. Initially, the typical approach builds on the growth of 3D cellular structures called embryoid bodies (EB). EBs are left to differentiate in a defined medium with FGF2 until neural rosettes appear or eventually become a predominant and distinguishable part of the EB [20]. In adherent conditions, a highly reliable protocol to generate NSCs introduces dual inhibition of SMAD signaling in iPSCs as the initial step ([25], See BOX 2 for further details). In this protocol, the inhibition of SMAD by both Noggin and SB431542 together with a specific initial density of cells leads to successful neural differentiation and formation of neural rosettes within 11 days [25]. This method generates a high number of $P A X 6+$ neural cells competent of rosette formation in as short as 11 days. However, in most cases, the neural conversion of iPSCs yields heterogeneous populations of NSCs and other neural cell types. Therefore, the isolation of NSCs from their niche remains a challenging and critical step in their further propagation. So far, few approaches have been introduced to address this problem. Selective enzymatic digestion has been used to separate neural rosettes and NSCs from EBs [20]. media. Media also often contain N2 and B27 Supplements. Thus, for complete protocols, refer to the respective references listed in the last column

Another approach achieved the enrichment of the population of NSCs by fluorescent activated cell sorting (FACS) based on the characteristic combination of cell-surface markers [27, 28]. Interestingly, a different combination of these surface markers can be used to sort neurons or glia. Other protocols reached the homogenous population of NSCs by manually picking and re-plating neural rosettes until a colony of morphologically identified NSCs was established and expanded [17, 19, 24]

Besides the protocols that recapitulate the developmental processes of differentiation, direct conversion of somatic cell types into induced NSCs (iNSCs) has also been explored to gain self-renewing populations of NSCs. The initial reprogramming of fibroblast into iNSCs was achieved using transient expression of four reprogramming factors (OCT4, $S O X 2, K L F 4, C-M Y C)$ in mouse embryonic fibroblasts under neural inductive conditions [29] or by using just three of these factors (SOX2, KLF4, and C-MYC) while limiting the expression of OCT4 [30]. Another study described a set of nine transcription factors (SOX2, KLF4, C-MYC, BRN2, ASCL1, NGN2, HES1, ID1, PAX6) to be efficient in converting mouse fibroblasts and Sertoli cells into iNSCs [31]. Eventually, the list of transcription factors narrowed to three 
(SOX2, FOXG1, and BRN2), or to SOX2 alone, respectively $[32,33]$, which have been demonstrated to assure the derivation of iNSCs from both mouse and human fibroblasts. Additionally, studies on human cord blood-derived CD133 + cells confirmed that overexpression of SOX2 alone, or in combination with $C-M Y C$ leads to the derivation of neuronal cells [34]. A small fraction of these cells then represented self-renewing neural progenitors. Lastly, two direct conversion protocols for iNSCs from peripheral blood mononuclear cells were recently reported $[35,36]$. Both approaches are based on transient overexpression of two (SOX2, C-MYC) or four (OCT4, SOX2, KLF4, and C-MYC) transcription factors in combination with a set of small molecule inhibitors, cytokines, and hypoxic conditions. Taken together, transcription factor SOX2 seems to be inevitable for the direct conversion of iNSCs and maintenance of their phenotype from both mouse and human somatic cells. However, for successful derivation of iNSCs, its overexpression should be always complemented by either other mentioned transcription factors, small molecules, cytokines, and/or hypoxic conditions.

BOX 2: BMP signaling and the "Dual SMAD" inhibition.

BMP signaling pathway is one of the major morphogenic regulators of embryonic development. As part of the TGF- $\beta$ superfamily, the role of the BMP protein family in this development is extensive. Studies of neural induction in vivo have shown that inhibition of BMP signaling is critical for the ectoderm to initiate the program of neural development. The binding of BMPs (especially BMP4) to the BMP receptor leads to the phosphorylation of SMAD1,5,9 proteins. Phosphorylated SMAD protein associates with SMAD4 and, translocated to the nucleus, acts as a transcription factor for genes driving epidermal differentiating programs. However, activation of TGF $\beta$ receptors leads to the phosphorylation of SMAD2,3 and their binding to SMAD4. In the nucleus, this complex induces mesodermal gene expression (reviewed in [13]). In the so-called "Dual SMAD" inhibition protocol, which is widely used to induce neural differentiation of iPSCs, both BMP and TGF $\beta$ signaling are inhibited simultaneously. Inhibitors and small molecules such as NOGGIN or LDN193189, and SB431542, respectively, drive the differentiation of iPSCs specifically towards neuroectoderm [25]

\section{Neurons}

In the context of neurodegenerative diseases, neurons are naturally the primary interest of the main research focus. Thus, to generate neurons in vitro, several methods can be employed depending on the experimental question that needs to be answered. The most straightforward approaches implement the fact that isolated neural rosettes or NSCs/ NPCs will, under non-self-renewing conditions, differentiate towards neurons spontaneously $[17,19,22]$. Therefore, either isolated rosettes or NSCs/NPCs are kept in the cell culture media without growth factors such as FGF2 or EGF. This strategy can be modified by adding specific growth factors/small molecules to enhance the speed of the differentiation towards neurons or to direct the differentiation towards specific neuronal subtypes [17, 19, 37] (See BOX 3 for further details). Usually, factors such as brain-derived neurotrophic factor (BDNF), glial cell line-derived neurotrophic factor (GDNF), cyclic adenosine monophosphate (cAMP), Forskolin, or RA are used. Additionally, a cocktail of small molecules that activate or inhibit developmental signaling pathways, such as dual SMAD inhibitors with Sonic hedgehog $(\mathrm{SHH})$ and $W N T$ signaling activators, are used in the case of forebrain dopamine neurons [38, 39]. It is also of note that the intrinsic level of Wnt signaling in iPSCs significantly influences the spatial and regional axes of neuronal development in vitro, and the effects of signaling differences can be rescued by exogenous pathway activation [40]. However, these differentiation methods all generate a mixed population of neurons and glia in a relatively lengthy process of at least 60 days in in vitro culture. For the neurons to become really mature and electrophysiologically active, the period of differentiation could be as long as $>100$ days [41]. Additionally, if pure neuronal culture is necessary for the final analysis, subsequent isolation of mature neurons via selection methods must be employed. Such selection methods could include FACS sorting [28] or selective isolation based on regulated cellular adhesion and suppression of growth of proliferating glial cells by AraC [42].

Additionally, some protocols directly stimulate iPSCs to form neurons without going through the stage of rosettes/NSCs/ NPCs. These either use small molecule inhibitors that, when added sequentially every (other) day to the cell culture medium, will predominantly transform the iPSCs towards a specific type of neurons within 16-20 days [43]. Alternatively, the transient overexpression of specific transcription factors became widely used to generate so-called "induced neurons" (iNs). The first successful generation of iNs from iPSCs was performed by forced expression of $B R N 2, A S C L 1$, and $M Y T 1 L$ transcription factors [44]. Eventually, it has been shown that overexpression of $N G N 2$ alone is sufficient to generate iNs that were morphologically mature in two weeks [45]. Following this research, the repertoire of protocols describing differentiation into various subtypes of neurons has widened. For example, forced expression of $A S C L$ and $D L X 2$ transcription factors in iPSCs has been shown to lead to the production of GABAergic iNs [46, 47]. A combination of both approaches, such as programming with transcription factor $N G N 2$ and inhibition of $S M A D$ and $S H H$, generated functional glutamatergic neurons [48].

The strategy of iNs, as described by Zhang and colleagues, has recently developed into a robust protocol that drives the differentiation of iPSCs into cortical neurons, 
referred to as the "i3N-i3neuron system" (i3 standing for integrated, inducible, isogenic). Based on the study of Zhang et al., where it has been shown that lentivirus-mediated expression of a single transcription factor $N G N 2$ is sufficient to induce rapid neurodifferentiation of iPSCs, a study by Wang et al. introduced an improved strategy where NGN2 transgene was stably integrated under doxycycline-inducible promoter into a safe-harbor locus in iPSCs. After 3-4 weeks of differentiation, generated i3Ns were mature and physiologically active when co-culturing with glia [49].

With all these available protocols, it is essential to adequately consider the research question asked as the differentiation method can influence the study results. For example, if the development-related question needs to be answered, it is more appropriate to let the neurons differentiate spontaneously without specific growth factors. These growth factors/small molecules could help neurons overcome possible problems that they would have if they were differentiating spontaneously. On the other hand, if the analysis requires a pure population of neurons or if the study is only done on the terminally differentiated neuronal population, then the homogenous population of sorted or induced mature neurons is likely the adequate model to use. However, it is essential to note that the absence of glia in such a model system might influence the experimental results if the studied mechanism also affects other cell types.

BOX 3 Small molecules and transcription factors in neuronal differentiation in vitro.

\footnotetext{
The most commonly used factors for neuronal differentiation in vitro are BDNF, GDNF, cAMP, Forskolin, and RA, all of which execute their functions via different mechanisms. BDNF binds TrkB receptor kinase and promotes the differentiation of progenitor cells into neurons [50]. GDNF acts as an activator of the ERK-1/2 and P13K/AKT pathways to support the survival of neurons [51]. cAMP activates CREB-mediated gene transcription associated with the dendritic length and the morphological maturity of the young neurons in a level-dependent manner [52]. The cellular level of cAMP can be raised by Forskolin, which activates the cAMP pathway [53]. RA, a powerful morphogene, activates RA receptor signaling and acts as an essential regulator in neural induction, proliferation, and differentiation [54]. Expression of BRN2, ASCL1, MYT1L transcription factors establishes and specifies the neural identity. Overexpression of the key transcription factor NGN2 rapidly affects complex mRNA and miRNA expression profile and mediates regulatory network mediating neurogenesis from stem cells in days [55]
}

\section{Astrocytes}

Astrocytes are the largest and most abundant glial cells within the human brain. Astrocytes were initially viewed as a predominantly supportive modulator of brain processes that engage in fundamental homeostatic processes, specifically in trophic, metabolic, protective, and detoxification functions. Specifically, these include the production of antioxidants, maintenance of the blood-brain barrier, synapse modulation, cytokine release, and metabolism of neurotransmitters, especially GABA and glutamate (reviewed in [56]). In contrast to these essential roles promoting neuronal functionality, reactive states of astrocytes induced upon cellular injury were repeatedly reported as toxic for neurons. Indeed, evidence of early/ late astrocytic reactivity has been repeatedly reported in numerous neurodegenerative diseases (review in [57]).

Over the last ten years, various protocols have been developed to differentiate iPSCs into astrocytes [41, 58-61]. Current iPSC-based methods for the differentiation of astrocytes typically rely on either NSCs/NPCs [61-65] or the oligodendrocyte progenitor cell [66] intermediates to form astrocytes via a cocktail of growth factors and small molecules (See BOX 4 for further details). These iPSC-differentiated astrocytes were shown to be functional also for cell-based models of neuropsychiatric disorders in vitro $[61,62,64,65]$ or engraftment in vivo $[62,63$, $66,67]$. Naturally, existing methods are slow (up to 6 months) $[61,63,66]$ or require sorting to reduce heterogeneity $[28,68]$. To overcome this complication, Tcw et al. (2017) identified a faster 30-day differentiation protocol adequate for the assays for a neuroinflammatory response, phagocytosis, and spontaneous calcium activity [41]. Additionally, protocols for induced astrocytes (iA) have also been published. Developed methods efficiently generate astrocytes in 4-7 weeks using the inducible expression of NFIA or NFIA and SOXIO in iPSCs [69-71].

Importantly, after the derivation of astrocytes from iPSCs, several studies also aimed to prove that they are functional and active correspondingly to their counterparts in vivo, thus usable for neurodegenerative disease modeling. Santos and co-workers compared a specific response to interleukin $1 \beta$ (IL-1 $\beta$ ) and tumor necrosis factor-alpha (TNF- $\alpha$ ) between iPSCs-derived astrocytes and human primary astrocytes. Both evoked pro-inflammatory responses with similar gene expression changes [72]. Furthermore, iPSCs derived astrocytes were also able to sequester $\mathrm{A} \beta$-plaques, exhibit altered $\mathrm{Ca}^{2+}$ homeostasis [73], display defective lipid metabolism [74], or switch into reactive astrocytes [72, 75].

BOX 4 Astrocytic differentiation and NFIA/SOX9.

Astrocytes can be differentiated from iPSCs, NSCs, or OPCs by exposure to a set of mitogens and morphogens such as Ciliary neurotrophic factor (CTNF), BMP, FGF2, Leukemia inhibitory factor (LIF), and Fetal bovine serum (FBS) in a manner mimicking physiological developmental stages [41, 76]. Canonically, CNTF, FGF2, and LIF activate the JAK/STAT pathways and BMPs signal primarily through SMAD pathways, eventually converging in the regulation of GFAP expression [77, 78]. Additionally, direct reprogramming of astrocytes is based on a transient expression of a transcription factor NFIA [71]. The acquisition of glial competency is associated with the lengthening or arrest of the G1 phase upon upregulation of CDKN1A in high NFIA levels. Similar results have been obtained by upregulation of NFIB and SOX9 [69] 


\section{Oligodendrocytes}

During development, oligodendrocyte progenitor cells (OPCs) give rise to mature oligodendrocytes, both of which are found in the mature CNS [79]. The key function of oligodendrocytes is to produce myelin and thus assure neuronal connectivity and axonal protection. Importantly, demyelination of neurons is often seen in neurodegenerative diseases [80].

The first protocol to describe the directed differentiation of oligodendrocytes from iPSCs was introduced by Nistor et al. in 2005 [81]. They used a combination of neurosphere formation followed by culturing cells in "glial restriction medium" and manual selection of OPCs. Their transplantation to shiverer mice resulted in integration, oligodendrocyte differentiation, and compact myelin formation, demonstrating that these cells display a functional phenotype [81]. Indeed, this protocol later led to the first human clinical trials of human embryonic stem cells (hESCs) derived OPCs for the treatment of acute spinal cord injury. Later, Izrael et al. (2007) differentiated oligodendrocyte progenitors from hESCs by firstly inducing the level of BMP by RA and its subsequent inhibition by NOGGIN. These cells were able to myelinate axons in mice brains as well as differentiate into mature oligodendrocytes [82]. Notably, Hsieh et al. (2004) published an important finding that Insulin growth factor-I (IGF-I) stimulates the differentiation of multipotent adult rat hippocampus-derived neural progenitor cells into oligodendrocytes [83]. This finding then stimulated the use of IGF-I in the differentiation protocols for iPSCs (See BOX 5 for further details) [84-88].

However, these initial protocols based on the recapitulation of the neural development of hESCs or iPSCs using growth factors alternation (such as RA, EGF, FGF2, SHH, or platelet-derived growth factor (PDGF)), cell culture adaptations with regards to extracellular matrix protein composition, and usage of small molecules like dual SMAD inhibitors, and ROCK inhibitor, have been dealing either with low yields or an exceptionally long differentiation procedure. New protocols, therefore, introduced shortened differentiation times due to forced expression of transcription factors. Notably, SRY-Box Transcription Factor 10 (SOX10) and Oligodendrocyte transcription factor $(O L I G 2)$ were identified as superior in oligodendrocyte cell-fate specification. Therefore their combination was used in protocols describing differentiation of iPSCs and NPCs into first oligodendrocyte progenitor cells followed by maturation into oligodendrocytes [46, 89-92]. Later, the overexpression of stably integrated single transcription factor $\mathrm{SOX} 10$ was demonstrated sufficient to convert iPSCs into myelinating oligodendrocytes in only 22 days [93]. Additionally, a combination of IGF-I with promyelinating drugs ketoconazole and clemastine has been used to promote oligodendrogenesis in 3D cortical spheroids, offering another approach to the generation of oligodendrocytes in complex differentiation strategies [94].

BOX 5: Pathways involved in oligodendrocyte differentiation.

\footnotetext{
Oligodendrocyte derivation often involves the generation of OPCs that serve as common precursors to both oligodendrocytes and astrocytes. OPCs can be produced from iPSCs through the use of various mitogens (e.g., FGF2, PDGF, and EGF) [95-98] and morphogens (like RA) or small molecules that promote SHH signaling (e.g., Smoothened agonist) or repress WNT/ $\beta$-catenin signaling $[99,100]$. Oligodendrocyte maturation from OPCs is often facilitated using IGF1 and triiodothyronine (T3). IGF1 seems to act through inhibition of BMP signaling (which induces maturation of OPCs into astrocytes) or through activation of ERK1/2 kinases [83, 101]. On the other hand, T3 was shown to upregulate transcription factor KLF9, which is likely involved in oligodendrocyte maturation [102]. Additionally, promyelinating drugs clemastine and ketoconazole inhibit enzymes for cholesterol biosynthesis, leading to the accumulation of sterol intermediates that promote maturation of OPCs into oligodendrocytes [94, 103]

Direct differentiation of NPCs into oligodendrocytes is achieved via overexpression of transcription factors such as SOX10, OLIG2, and NKX6.2 [104]. These directly or indirectly affect the expression of genes involved in oligodendrocyte differentiation, such as PDGF receptor alpha (PDGFRA) or negative regulator of hedgehog signaling SUFU [105-108]. SOX10 was identified as a key transcription factor that was successfully used alone for oligodendrocyte differentiation. However, care must be taken when selecting the protocol for NPC generation as it may potentially affect the success rate of oligodendrocyte differentiation using SOX10 only [93]
}

\section{Microglia}

Microglial cells are part of the innate immune system and represent the mesoderm-derived cell type present in the human brain. Specifically, microglial cells originate from c-Myb-independent primitive macrophages present in embryonic yolk-sack. These primitive macrophages then migrate through embryonic vasculature, finally reaching primitive neuroepithelium and subsequently colonizing developing brain parenchyma [109]. They play numerous vital roles in brain development, homeostasis, and regulation of neuroinflammation [110].

The first microglia differentiation protocol was not presented until 2016 by Muffat et al. [111]. Since then, many protocols have been introduced and recently reviewed (See BOX 6 for further details) [112]. Interestingly, two strategies to gain microglia arose out of the published protocols. The first relies on the formation of yolk sack EBs, which are further differentiated into microglia-like precursor cells and microglia-like cells $[111,113]$. Another differentiation scheme produces microglia-like cells through the stage of 
hematopoietic precursors $[114,115]$. In these protocols, a cocktail of growth factors including BMP4, FGF2, vascular endothelial growth factor A (VEGF-A) together with different types of interleukins is supplemented to direct the differentiation. Also, co-culture with supportive cell lines, either astrocytes [116] or neurons [117], which provide the cells with essential factors, represent another possible and faster approach in deriving a mixed population of microglialike cells.

It is of note that the results of in vitro differentiation into microglia are referred to as "microglia-like" cells since broad consensus on phenotypic and genotypic markers of these cells regarding their in vivo counterparts has not yet been fully established.

BOX 6 Inducible microglia.

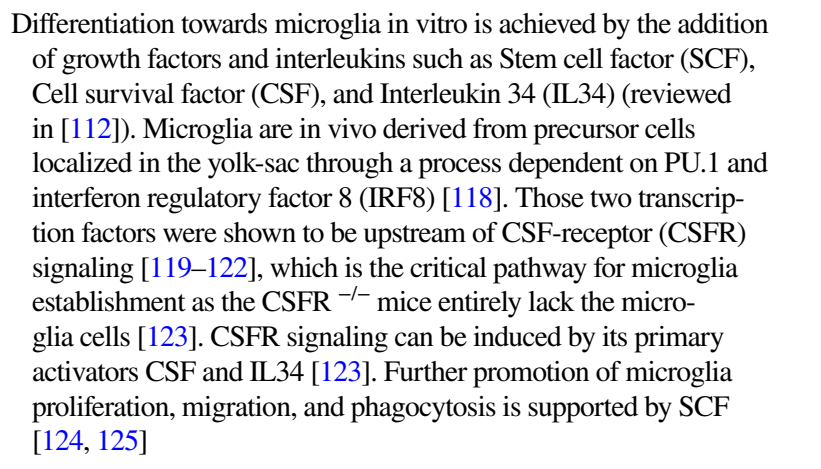

\section{Transdifferentiation Strategies}

Over the last years, the accuracy of iPSCs-derived cellular models of neurodegenerative diseases has been questioned. This concern was mainly because the generation of iPSCs from somatic cells is accompanied by the juvenilization of these cells into an embryonic-like state. This juvenilization can be traced in epigenetic modifications, telomerase length, and other aspects, including mitochondria condition [126-128]. Therefore, the aging phenotype of the differentiated cells derived from iPSCs seems not to correspond to their in vivo counterparts. Even though these properties make iPSCs-derived neural cell types great candidates for transplant therapies, their ability to recapitulate pathological features of age-associated neurodegenerative diseases with late-onset in vitro is considered limited (reviewed in [129-131]).

As a possible strategy to bypass this limitation, overexpression of progerin, a truncated form of lamin A associated with premature aging, has been shown to trigger neuronal aging phenotypes in iPSCs-derived neurons [132]. Furthermore, telomerase inhibition in iPSCs and subsequent neural differentiation has effectively shortened telomeres and thus provoked age-related phenotype in dopamine neurons [133].
Additionally, the application of chemical factors resulted in increased stress and, by consequence, the aging phenotype in cultured neuronal cells. Notably, in some cases, only after additional aging promoting elements were added was the studied neurodegenerative disease fully manifested [134].

A different way to preserve age-associated features in cells is the transdifferentiation of somatic cells directly to the desired cell type (reviewed in $[130,131,135])$. This method has caught emerging attention in neurodegenerative disease modeling. The first conversion of human fibroblasts has been carried out by overexpression of BRN2, ASCL1, MYT1L, and NEURODI [44]. These factors have also been used to reprogram human hepatocytes into iNs [136]. Since then, protocols have introduced alternative combinations of reprogramming transcription factors and microRNAs to direct somatic cells into neuronal lineage [137-139]. So far, many protocols to generate dopaminergic, glutamatergic, cholinergic, GABAergic, and other neurons have been developed (reviewed in [130]). Importantly, avoiding the iPSCs stage, transdifferentiated iNs were shown to conserve the agerelated epigenetic landscape and other cellular properties from the cell of origin $[138,140]$. Therefore, deriving aged neural cell types adequately without the need to induce aging in vitro is undoubtedly beneficial for neurodegenerative disease modeling. However, recent work shows extensive de novo DNA methylation occurs in mouse fibroblasts directly converted to neurons using BAM factors [141]. While this study suggests that this epigenetic remodeling promotes a neuronal epigenetic landscape, a more detailed analysis of epigenome remodeling that may occur in directly converted human neurons in aged or disease states is warranted.

\section{D Brain Organoids}

Cerebral organoids are iPSCs derived self-assembled 3D cellular aggregates mimicking human fetal brain development $[7,142]$. They display multiple relevant cell types that undergo intrinsic developmental patterns of a particular modeled organ. Additionally, an organoid's ability to obtain specialized functions ordinarily present in a modeled organ proved to be a novel tool for studying the human brain. A $3 \mathrm{D}$ cerebral organoid organ-like organization can be subsequently used to investigate human fetal brain development, tissue organization, aging, metabolic processes, drug screening, and disease modeling (reviewed by [143]).

Derivation of human cerebral organoids nowadays relies on both guided and unguided methods (reviewed by [144]). Initially, protocols were dependent on stem cells' intrinsic ability to assemble and differentiate towards the neuronal fate. This approach led to the formation of whole-brain 3D organoids with different regions within the organoid [142]. Subsequent protocols modified the original procedure to form region-specific cerebral organoids. Those "guided" 
organoids are directed by region-specific growth factors, differentiation factors, and specific cellular inhibitors. For this reason, region-specific cerebral organoids are more representative of cellular composition, structural features, and molecular processes of particular brain regions modeled [144]. Since then, region-specific organoids such as cortical spheroids [145], cerebellar organoids [146], hippocampal organoids [147], and midbrain organoids [148] were established, contributing to our understanding of brain region specificities.

Notably, refinements of 3D cerebral organoid cultures opened new possibilities for investigating human brain disorders in vitro and possibly overcoming the gap between in vitro human cell-based systems and animal models. Indeed, animal models often fail to reproduce humanspecific pathology. However, even 2D human cellular cultures are misrepresentative of complexly interacting in vivo environments. Therefore, the intricate 3D organization of cerebral organoids, especially considering the extracellular deposition of pathological proteins in vast neurodegenerative diseases, proves to open new research possibilities. Another well-addressed advantage of cerebral organoids is their potential to establish patient-derived models with the principal characteristic of a patient's genetic information. Indeed, first patient-derived 3D cerebral are starting to be used, for instance, in drug-screening (reviewed by [149]) and glioblastoma research [150], thus opening new possibilities in personalized medicine. Despite current advancements in cellular biology, several limitations (e.g., heterogeneity, lack of vascularization, aging) need to be addressed to match all principal aspects of human brain physiology. Despite these limitations, cerebral organoids hold the promising potential to establish fresh new insights into neurodegenerative disease modeling.

\section{Alzheimer's Disease}

Alzheimer's disease (AD) is a chronic neurodegenerative disease characterized by loss of neurons in the cerebral cortex and subsequent cortical dysfunction. It is the most common form of dementia, with $60-80 \%$ of all dementia cases significantly contributing to morbidity/mortality rates in the elderly population worldwide. There are two forms of AD-familial (fAD; 5\%) and sporadic (sAD; 95\%). The vast majority of fAD is associated with mutations in the Amyloid Precursor Protein (APP), Presenilin 1 and 2 (PSEN1 and PSEN2) genes [151]. However, since most AD cases are considered sporadic, $\mathrm{SAD}$ is presumably triggered by the interplay of genetic and environmental factors with unclear etiology [151]. One of the major risk factors associated with sAD is the APOE4 allele, with almost $65-80 \%$ of $\mathrm{AD}$ patients. In contrast, the APOE2 allele is considered a protective factor. Apart from $A P O E$, genome-wide association studies have identified more than 20 AD risk genes, including SORL1 or TREM2, and detailed studies of these in the field of iPSCs are beginning to emerge [152-154].

Clinically, AD-associated progressive memory loss is underlaid by two main pathological features present in the AD brain: 1) extracellular beta-amyloid plaques and 2) intraneuronal Tau-containing neurofibrillary tangles. Hallmarks of the first feature include the accumulation of insoluble deposits of amyloid $\beta$ peptides (i.e., "A $\beta$ plaques") cleaved from APP protein. APP is critical to neural stem cell development, neuronal survival, neurite outgrowth, and neuronal repair. It is, under physiological conditions, cleaved to short peptides by alpha, beta, and gamma secretases to perform its function. Gamma-secretase then consists of PSEN1 and PSEN2 subunits. Produced A $\beta$ peptides are under physiological conditions predominantly 40-mers (A $\beta 40)$, but in the case of pathological mutations in APP or PSEN1/2 genes, the 42-residue peptides (A $\beta 42)$ are overrepresented [155]. These $A \beta 42$ peptides have a markedly higher propensity to aggregate in comparison with $\mathrm{A} \beta 40$, causing the formation of dense, mostly insoluble deposits of $A \beta$ plaques in the extracellular matrix. According to this "Amyloid hypothesis", the deposition progressively leads to synaptic dysfunction, inflammation, neuronal loss, and, ultimately, dementia [156].

The second feature leading to AD pathology is "Neurofibrillary tangles", insoluble aggregates of hyperphosphorylated microtubule-associated protein Tau. Tau protein is phosphorylated by a number of kinases (e.g., CDK5, GSK3, and others), and its abnormal phosphorylation promotes the polymerization and formation of insoluble filaments. Tangles then accumulate intracellularly within neuronal soma, resulting in the collapse of the axonal transport system [156]. However, the process of aggregation of hyperphosphorylated Tau (P-TAU) in the absence of causative mutation is unknown, and the exact relationship between P-TAU and $A \beta$ has been elusive so far. Moreover, numerous clinical trials aiming to prevent P-TAU and/or A $\beta$ deposition failed to demonstrate the effectiveness of disease-modifying treatments. This suggests that our understanding of the molecular basis of $\mathrm{AD}$ is incomplete and implies that protein aggregation is perhaps not a cause but rather a consequence of unknown mechanism(s) that eventually lead to AD pathology. Taken together, despite a rising number of publications and data, the exact pathophysiologic mechanisms underlying $\mathrm{AD}$ is still mostly unknown.

The broad applicability of different AD-based iPSCs significantly contributed to the current understanding of AD. Still, an increasing number of AD-iPSCs in repositories from patients with $\mathrm{SAD}$ or $\mathrm{AAD}$ or genetically manipulated cell lines [158-160] in combination with precisely refined cellular differentiation protocols into neurons, all central 
glial cells and microglia represent an efficient method for examination of AD. This may not be limited to etiopathogenesis, pathophysiology, molecular pathology, and drug testing of Alzheimer's disease. Here we provide an overview of major iPSCs-derived cellular AD models in vitro and summarize the significant findings from these models in Fig. 2. Additionally, we also encourage readers to explore other relevant reviews on this topic as they provide a different perspective on $\mathrm{AD}$ development and in vitro modeling [161-168].

\section{NSCs and Progenitor Cells}

Although the majority of the AD-iPSC studies focused on studying neurons, there are, to this date, six reports that, at least to some extent, addressed the phenotype, behavior, and/ or molecular changes coupled to AD specifically in NSC/ NPCs [169-175]; see Table 1 for details). In the first study, Koch et al. [170] used lentiviral transgenesis and introduced fAD-causing mutations in PSENI (L166P, D385N) to longterm self-renewing NSCs derived from hESCs. The study shows that the expression of APP and A $\beta$ secretion is maturation-dependent. They detected very low levels of APP and $A \beta$ in self-renewing NSCs while the expression of both proteins increased to detectable levels only after three weeks of neuronal differentiation in vitro. Upon introducing mutant PSEN1 variants to NSCs, they showed no effect on apoptosis, but significant downregulation of proliferation compared to wild-type PSEN1 transduced NSCs [170].

However, the next two studies did not find any specific aberrations in NSCs that would be related to AD phenotype. Sproul et al. [173] generated iPSCs from affected and unaffected individuals from two families carrying PSEN1 mutations (A246E and M146L). PSEN1 mutant NPCs had greater ratios of $A \beta 42$ to $A \beta 40$ relative to their control counterparts but did not show any aberrations in proliferation. Molecular profiling identified only 14 genes differentially expressed in PSEN1 NPCs relative to control NPCs, including NLRP2, $A S B 9$, and $N D P$ [173]. Later, Jones et al. [169] reported the generation of human iPSCs from healthy individuals and patients with either early-onset fAD (PSEN1 M146L) or the late-onset SAD (carrier of APOE4/4). They also report no significant differences in NPC growth rates or NPC marker expression (PAX6 and NESTIN). No significant difference was detected in the efficiency of early neuronal induction (measured by the proportion of $\beta$-III-tubulin + neurons) between any individual. Both SAD and fAD NPCs retained their characteristic morphology, expression of canonical markers and were able to generate mature cortical neurons with the same efficiency as control NPCs [169].

Interestingly, a recently published (and perhaps the most detailed) study was performed by Meyer et al. [171]. They generated iPSCs from a larger cohort of sAD patients and age-matched controls. Gene expression analysis of sADNPCs showed a marked increase in the expression of neural differentiation-related genes (including ASCL1/MASH1, $D C X, M A P T, C D 24$, and STMN2), premature neuronal differentiation (a finding supported by the study of Yang et al. [174]) and reduced NPCs self-renewal. Importantly, this phenomenon was not caused by the APOE4/4 genotype as $A P O E 3 / 3$ sAD cell lines showed the same trend [171]. Functional analysis of the transcriptome of SAD NPCs (and neurons) suggested that upregulated genes were regulated by the transcriptional repressor REST (repressor element 1-silencing transcription factor). Indeed, sAD NPCs showed reduced nuclear REST levels and REST-RE1 site binding. A similar differentiation phenotype and involvement of REST were observed in isogenic neural cells generated from iPSCs that were gene-edited to express APOE4. Conversely, gene editing of $A P O E 4$ to the neutral allele $A P O E 3$ reversed the phenotype. Finally, they were able to show that the loss of function of REST in SAD and upon APOE4 expression was due to reduced nuclear translocation and chromatin binding and was associated with disruption of the nuclear lamina. These findings suggest that REST dysfunction and epigenetic dysregulation emerge in SAD and APOE4 NPCs and persist in differentiated neurons, potentially contributing to the onset of $\mathrm{AD}$ [171].

Taken together, it would seem that while some fAD causing mutations in PSEN1 might not affect the properties of NPCs [169, 173], there are at least some fAD and sADpatient's derived NSCs that show a significant decrease in proliferation, downregulation of NSC-specific markers, upregulation of early neuronal markers and show signs of premature differentiation [170, 171, 174]. Meyer et al. further show that in $\mathrm{SAD}$, this is due to the inactive REST complex and the disruption of the nuclear lamina. These findings raise the possibility that a developmental perturbation, such as the depletion of NSCs or altered neural circuit formation, may occur early in life in individuals predisposed to develop sAD. Moreover, while this may not significantly compromise cognitive function in young adults, it may increase the risk of neurodegeneration and cognitive decline when combined with chronic stressors later in life [171].

\section{Neuronal Models}

To this date, over 50 studies were published that focused on studying $\mathrm{AD}$ and $\mathrm{AD}$-related phenotypes using iPSCderived neurons (See Table 1 for details). These reports mainly focus on studying fAD mutations in APP, PSEN1, and PSEN2 or employ the strategy of iPSCs generation from sAD patients, although CRISPR/Cas9 gene-edited cell lines are being used more and more often. Several studies then specifically focused on addressing the role of APOE4 genotype, other risk factors (SORL1 or TREM2), or mutant TAU 


\section{Human Induced Pluripotent Stem Cells}

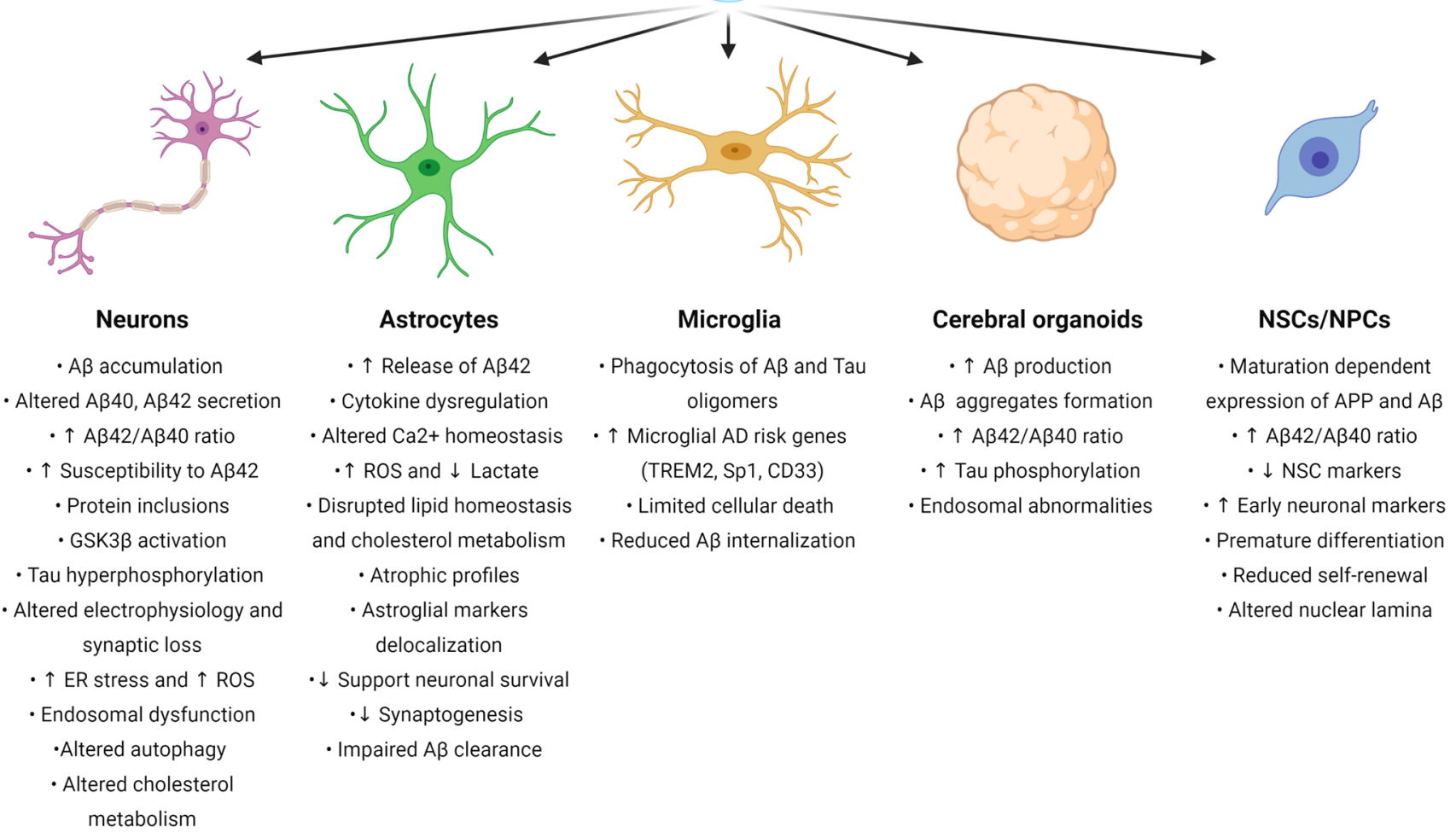

Fig. 2 Major finding from stem-cell-based models of AD. For each cell type, we summarize significant results presented in Sect. 3. “ $\uparrow$ " represents upregulation or increase, “ $\downarrow$ ” represents downregulation or decrease

on AD development. Methodologically, they employ a large variety of differentiation protocols for neuronal derivation ranging from glutamatergic [176], GABA-ergic [177], and dopaminergic subtypes to basal forebrain cholinergic neurons [178, 179], and several studies also use direct transdifferentiation, generating iNs $[140,180]$.

In general, initial studies using iPSCs-derived neurons demonstrated the presence of typical AD pathological features in these cultures. They described 1) $A \beta$ accumulation in cell cultures; 2) altered secretion of $A \beta 40$ and/or $A \beta 42$ peptides; 3 ) the presence of protein inclusions; 4 ) activation of glycogen synthase kinase 3 beta (GSK3 $\beta$ ); and 5) TAU hyperphosphorylation (summarized in Table 1). Subsequent studies validated that AD-iPSC-derived neurons can also demonstrate 6) loss of synapses and decreased synaptic plasticity $[181,182], 7)$ altered electrophysiological activity [93], 8) increased oxidative stress and reactive oxygen species (ROS) generation [183, 184], 9) endosomal dysfunction [185], 10) defective autophagy, mitophagy and mitochondrial abnormalities [186-188], and 11) altered cholesterol metabolism [189]. These pathologies were found both in fAD and sAD-iPSC-derived neurons, albeit not all fAD/sAD cell lines displayed all the pathological signs. One of the aspects possibly playing an important role in this phenomenon is the finding of Muratore et al., who reported that generation of $A \beta$ plaques and the responsiveness of TAU to $A \beta$ are affected by neuronal cell type with rostral neurons being more sensitive than caudal neurons [190]. Nevertheless, the application of $\beta$ - or $\gamma$-secretase inhibitors (and possibly other small molecule inhibitors) in majority of the studies resulted in the reduction of $A \beta$ peptides secretion and downregulation of P-TAU, thus confirming the possibility to use these in vitro models for drug discovery approaches [152, 170, 185, 191-196].

Numerous studies also investigated the effects of $A \beta$ oligomers in AD iPSCs-derived neuronal cultures. In general, fAD neurons displayed a high $\mathrm{A} \beta 42 / \mathrm{A} \beta 40$ ratio $[73,170$, $172,192,193,197]$. Interestingly, increased $A \beta$ oligomers have been shown to induce endoplasmic reticulum stress and ROS generation [198]. Indeed, increased oxidative stress and ROS-mediated cellular dysfunction were documented in both $P S E N I^{A 246 E}[199]$ and mutant $A P P^{4693 E}$ neurons [198]. Recently, A $\beta 42$ oligomers were also reported to provoke mitochondrial DNA damage and decrease the 
Table 1 List of publications utilizing human iPSC-derived neural models for studying Alzheimer's disease

\begin{tabular}{|c|c|c|c|}
\hline Reference & Cellular & Type of AD/ & Most relevant results \\
\hline & model & Mutation & \\
\hline $\begin{array}{l}\text { Sproul et al., } \\
2014 \text { [172] }\end{array}$ & NPCs & $\begin{array}{l}\text {-fAD PSEN1 A246E } \\
\text { •fAD PSEN1 M146L }\end{array}$ & $\begin{array}{l}\text {-PSEN1 NPCs produced greater ratios of } A \beta 42 \text { to } A \beta 40 \text { relative } \\
\text { to their control counterparts; - Molecular profiling identified } 14 \\
\text { genes differentially regulated in PSEN1 NPCs relative to control } \\
\text { NPCS with altered pathways including NLRP2, ASB9, and NDP; }\end{array}$ \\
\hline $\begin{array}{l}\text { Yang et al., } \\
2017[173]\end{array}$ & NPCs & $\begin{array}{c}\text {-fAD PSEN1 } \\
\text { S169del } \\
\text {-fAD PSEN1 A246E }\end{array}$ & $\begin{array}{l}\text { - Premature neuronal differentiation with decreased } \\
\text { proliferation and increased apoptosis; }-N P C s \text { differentiation } \\
\text { culture elevated ratio of } A \beta 42 / A \beta 40 \text { and neurite fragmentation; }\end{array}$ \\
\hline \multirow{3}{*}{$\begin{array}{l}\text { Meyer et al., } \\
2019[170]\end{array}$} & NPCs & \multirow[b]{3}{*}{$\begin{array}{l}\cdot \text { CRISPR/Cas9 edit: } \\
\text { APOE4 }\end{array}$} & \multirow{3}{*}{$\begin{array}{l}\text {-SAD NPCS exhibit accelerated neural differentiation, and } \\
\text { reduced progenitor cell renewal; •SAD and APOE4 expression } \\
\text { resulted in reduced REST nuclear translocation and chromatin } \\
\text { binding, and disruption of the nuclear lamina; }\end{array}$} \\
\hline & Neurons & & \\
\hline & Organoids & & \\
\hline $\begin{array}{l}\text { Pansri et al., } \\
2021[174]\end{array}$ & NPCs & -fAD PSEN1 V89L & $\begin{array}{l}\text { - BDNF increases proliferation of NPCs irrespectively of the } \\
\text { disease state; } \bullet \text { Shorter neurite length in FAD-NPCs; }\end{array}$ \\
\hline $\begin{array}{l}\text { Yagi et al., } \\
2011[151]\end{array}$ & $\begin{array}{l}\text { Cortical } \\
\text { neurons }\end{array}$ & $\begin{array}{l}\text {-fAD PSEN1 A246E } \\
\text { •fAD PSEN2 N141I }\end{array}$ & $\begin{array}{l}\text {-fAD neurons have increased } A \beta 42 \text { secretion; } \bullet \psi \text {-secretase } \\
\text { inhibitor and } A \beta 42 \text { inhibitor reduced } A \beta 42 \text {; }\end{array}$ \\
\hline $\begin{array}{l}\text { Israel et al., } \\
2012[175]\end{array}$ & Neurons & $\begin{array}{l}\bullet \text { fAD APP dup } \\
\qquad \text {-sAD }\end{array}$ & 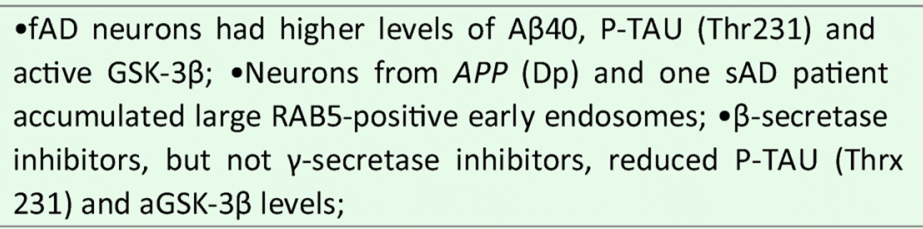 \\
\hline $\begin{array}{l}\text { Koch et al., } \\
2012[169]\end{array}$ & $\begin{array}{l}\text { NSCS } \\
\text { Cortical } \\
\text { neurons }\end{array}$ & $\begin{array}{l}\text { Lentiviral } \\
\text { transgenesis: } \\
\text {-PSEN1 L166P } \\
\text {-PSEN1 D385N }\end{array}$ & $\begin{array}{l}\text {-PSEN1 } L 166 P \text { mutation resulted in elevated } A \beta 42 / 40 \text { ratio } \\
\text { caused by a selective decrease in } A \beta 40 \text { production and partial } \\
\text { loss of } \gamma \text {-secretase function; } \bullet \text {-secretase inhibitor and non- } \\
\text { steroidal anti-inflammatory drugs reduced } A \beta 42 \text {; }\end{array}$ \\
\hline $\begin{array}{l}\text { Shi et al., } \\
2012 \text { [176] }\end{array}$ & Neurons & $\begin{array}{l}\bullet \text { Down Syndrome } \\
\text { (extra copy of APP) }\end{array}$ & $\begin{array}{l}- \text { Elevated secretion of } A \beta 40 \text { and } A \beta 42 ; \bullet A \beta 42 \text { formed insoluble } \\
\text { intracellular and extracellular aggregates; •Production of } A \beta \\
\text { peptides blocked by a gamma-secretase inhibitor; } \bullet P-T A U \\
\text { localized to cell bodies and dendrites; }\end{array}$ \\
\hline \multirow[b]{2}{*}{$\begin{array}{l}\text { Kondo et al., } \\
2013 \text { [177] }\end{array}$} & Neurons & \multirow[b]{2}{*}{$\begin{array}{l}\text {-fAD APP E693 } \\
\text {-fAD APP V717L } \\
\text { •SAD }\end{array}$} & \multirow{2}{*}{$\begin{array}{l}\text {-A } \beta \text { oligomers accumulated in neurons and astrocytes in cells } \\
\text { from patients with a familial } A P P E 693 D \text { mutation and one of the } \\
\text { two } S A D \text {, leading to ER and oxidative stress; -Docosahexaenoic } \\
\text { acid (DHA) treatment alleviated the stress responses, but the } \\
\text { amount of } A \beta \text { oligomers in cell lysates was not altered; }\end{array}$} \\
\hline & Astrocytes & & \\
\hline $\begin{array}{l}\text { Woodruff et } \\
\text { al., } 2013 \\
{[178]}\end{array}$ & $\begin{array}{l}\text { Cortical } \\
\text { neurons }\end{array}$ & $\begin{array}{l}\text { TALEN-induced } \\
\text { PSEN1 mutations: } \\
\bullet \text { (WT/null; } \\
\text { WT/ } \Delta \mathrm{e} 9 ; \Delta \mathrm{e} 9 / \Delta \mathrm{e} 9 \\
\quad \Delta \mathrm{e} 9 / \text { null })\end{array}$ & 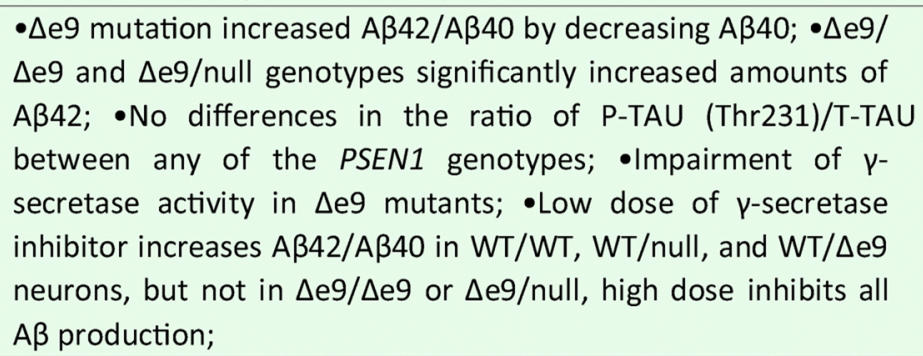 \\
\hline $\begin{array}{l}\text { Duan et al., } \\
2014 \text { [179] }\end{array}$ & $\begin{array}{l}\text { Basal } \\
\text { forebrain } \\
\text { cholinergi } \\
\text { c neurons } \\
\text { (BFCN) }\end{array}$ & $\begin{array}{c}\text { •fAD PSEN1 A246E } \\
\text { •SAD APOE3/E4 }\end{array}$ & 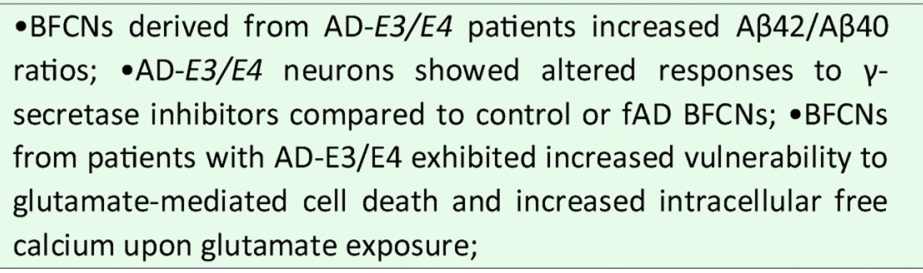 \\
\hline
\end{tabular}


Table 1 (continued)

\begin{tabular}{|c|c|c|c|}
\hline $\begin{array}{l}\text { Liu et al., } \\
2014 \text { [180] }\end{array}$ & Neurons & $\begin{array}{l}\text { - fAD PSEN1 A246E } \\
\text { - fAD PSEN1 H163R } \\
\text { - fAD PSEN1 M146L }\end{array}$ & $\begin{array}{l}- \text { Elevated } A \beta 42: 40 \text { ratio; } \bullet \text { Non-steroidal anti-inflammatory drug } \\
\text { like GSM reduced } A \beta 42, A \beta 40 \text {, and } A \beta 38 \text { and the } A \beta 42: 40 \text { ratio, } \\
\text { but no change in the total } A \beta \text { levels; }\end{array}$ \\
\hline $\begin{array}{l}\text { Mahairaki et } \\
\text { al., } 2014 \\
{[181]}\end{array}$ & Neurons & -fAD PSEN1 A246E & eased $A \beta 42 / A \beta 40$ ratio; • Increased soluble APP; \\
\hline $\begin{array}{l}\text { Maloney et } \\
\text { al., } 2014 \\
{[182]}\end{array}$ & Neurons & $\begin{array}{c}\bullet A P P A 673 T \\
\text { (Protective variant) }\end{array}$ & $\begin{array}{l}\text { - APP A673T shows reduced cleavage by BACE1; } \bullet A 673 T \text { reduces } \\
\text { amyloidogenic processing of APP and mildly decreases A } \\
\text { aggregation; }\end{array}$ \\
\hline $\begin{array}{l}\text { Muratore et } \\
\text { al., } 2014 \\
{[183]}\end{array}$ & Neurons & $\begin{array}{l}\text {-fAD APP V717I } \\
\text { (London) }\end{array}$ & $\begin{array}{l}\bullet \text { Increased generation of } A \beta 42, A \beta 38 \text {; Increased T-TAU and P- } \\
\text { TAU; } \bullet \text { Co-localization of APP and endosome; } \bullet \text { Increased } \beta \text { - } \\
\text { secretase activity; } \bullet \text {-secretase inhibitors decrease } A \beta ; \bullet A \beta \\
\text { specific antibody reduces T-TAU; }\end{array}$ \\
\hline $\begin{array}{l}\text { Chang et al., } \\
2015 \text { [184] }\end{array}$ & Neurons & $\begin{array}{l}\text {-Down Syndrome } \\
\text { (extra copy of APP) }\end{array}$ & $\begin{array}{l}\bullet \text { Accumulated } A \beta \text { deposits; } \bullet \text { TAU hyperphosphorylation and } \\
\text { TAU intracellular redistribution; } \bullet N \text {-butylidenephthalide reduced } \\
\text { secreted } A \beta 40 \text { deposits, the total TAU and P-TAU; }\end{array}$ \\
\hline $\begin{array}{l}\text { Hossini et al., } \\
2015 \text { [152] }\end{array}$ & Neurons & -sAD & 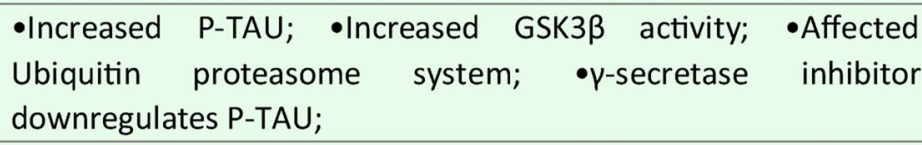 \\
\hline $\begin{array}{l}\text { Hu et al., } \\
2015 \text { [43] }\end{array}$ & Neurons & $\begin{array}{l}\text {-fAD APP V717I } \\
\text {-fAD PSEN1 } \\
\text { I167del } \\
\text {-fAD PSEN1 A434T } \\
\text {-fAD PSEN1 } \\
\text { S169del }\end{array}$ & 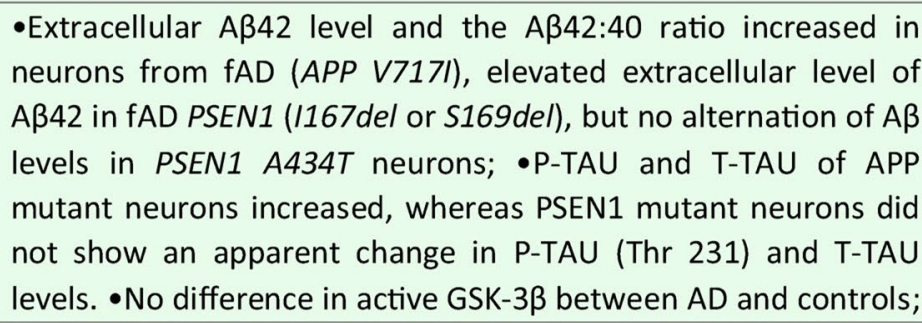 \\
\hline $\begin{array}{l}\text { et al., } \\
\text { 185] }\end{array}$ & $\begin{array}{l}\text { Cortical } \\
\text { neurons }\end{array}$ & $\begin{array}{l}\text {-fAD APP V717I } \\
\text {-fAD APP dup } \\
\text { •fAD PSEN1 } \triangle / 4 \\
\text { •fAD PSEN1 Y115C }\end{array}$ & $\begin{array}{l}-N e u r o n s \text { from different genetic forms of Alzheimer's disease } \\
\text { differ in APP processing; •Increased A A } 42: 40 \text { ratio; •APP } \\
\text { metabolism regulates TAU proteostasis: •APP (but not PSEN1) } \\
\text { leads to increased T-TAU and P-TAU; • } \vee \text {-secretase inhibitor } \\
\text { increases intracellular TAU, while } \beta \text {-secretase inhibitor reduces } \\
\text { it; }\end{array}$ \\
\hline $\begin{array}{l}\text { Nieweg et } \\
\text { al., } 2015 \\
{[186]}\end{array}$ & $\begin{array}{l}\text { Cortical } \\
\text { neurons }\end{array}$ & -fAD APP V717F & $\begin{array}{l}\text {-Neurons strongly susceptible to the synaptotoxic actions of } A \beta \text {; } \\
\text {-Application of } A \beta \text { for eight days led to a loss of vesicle clusters; } \\
\text {-Impaired postsynaptic AMPA receptors; }\end{array}$ \\
\hline $\begin{array}{l}\text { Young et al., } \\
2015 \text { [153] }\end{array}$ & $\begin{array}{l}\text { Cortical } \\
\text { neurons }\end{array}$ & $\begin{array}{l}\text {-SORL1 risk (R) vs. } \\
\text { protective }(P) \\
\text { variants }(N=4 P / P \text {, } \\
\quad 6 P / R, 3 R / R)\end{array}$ & $\begin{array}{l}- \text { Protective variant increased SORL1 expression and reduce } A \beta \\
\text { after BDNF treatment; } \bullet \text { Risk variant show a reduced response to } \\
\text { treatment with BDNF, at the level of both SORL1 expression and } \\
\text { APP processing; }\end{array}$ \\
\hline $\begin{array}{l}\text { Paquet et al., } \\
2016 \text { [171] }\end{array}$ & $\begin{array}{l}\text { Cortical } \\
\text { neurons }\end{array}$ & $\begin{array}{l}\text { CRISPR/Cas9 } \\
\text { induced: } \\
\text {-APP Swedish } \\
\text {-PSEN1 M146V }\end{array}$ & $\begin{array}{l}\text { - Genotype-dependent disease-associated phenotypes: } \\
\text { Increased } A \beta 42: 40 \text { ratio in a dose-dependent manner of the } \\
\text { mutation; }\end{array}$ \\
\hline $\begin{array}{l}\text { Woodruff et } \\
\text { al., } 2016 \\
{[187]}\end{array}$ & $\begin{array}{l}\text { Cortical } \\
\text { neurons }\end{array}$ & $\begin{array}{l}\text {-fAD PSEN1 } \triangle e 9 \\
\text { •fAD APP V717F } \\
\text {-fAD APP Swedish }\end{array}$ & $\begin{array}{l}\text {-fAD mutant neurons display abnormal endocytosis (defects in } \\
\text { the recycling state of endocytosis) and soma-to-axon } \\
\text { transcytosis of APP and lipoproteins that are mediated by } \\
\text { Rab11; • Accumulation of } \beta \text {-CTFs of APP, but not } A \beta \text {, slow vesicle }\end{array}$ \\
\hline
\end{tabular}


Table 1 (continued)

\begin{tabular}{|c|c|c|c|}
\hline & & & $\begin{array}{l}\text { formation from an endocytic recycling compartment; } \\
\text { - Endocytosis rescued by a } \beta \text {-secretase inhibitor; }\end{array}$ \\
\hline $\begin{array}{l}\text { Armijo et al., } \\
2017[188]\end{array}$ & Neurons & $\begin{array}{l}\bullet \text { fAD PSEN1 A246E } \\
\bullet \text { •SAD }\end{array}$ & $\begin{array}{l}\text {-fAD neurons secrete a higher concentration of } A \beta 42 \text {; } \bullet A D \\
\text { neurons more susceptible to the toxicity of } A \beta 42 \text { oligomers than } \\
\text { healthy cells; }\end{array}$ \\
\hline $\begin{array}{l}\text { Dashinimaev } \\
\text { et al., } 2017 \\
{[189]}\end{array}$ & $\begin{array}{l}\text { Neural } \\
\text { cells }\end{array}$ & $\begin{array}{l}\text {-Down Syndrome } \\
\text { (extra copy of APP) }\end{array}$ & $\begin{array}{l}\text {-Increased secretion and accumulation of } A \beta \text { granules of } A B 42 \text {; } \\
\text { - Upregulated expression of the } A P P \text { gene; } \bullet \text { Increased expression } \\
\text { levels of genes associated with AD (BACE2, RCAN1, ETS2, } \\
\text { TMED10); }\end{array}$ \\
\hline $\begin{array}{l}\text { Martin- } \\
\text { Maestro et } \\
\text { al., } 2017 \\
{[190]}\end{array}$ & $\begin{array}{l}\text { Neurons } \\
\text { (and } \\
\text { Fibroblast } \\
\text { s) }\end{array}$ & •fAD PSEN1 A246E & $\begin{array}{l}\text {-Mitophagy impairment and diminished autophagy degradation } \\
\text { phase associated with lysosomal anomalies; •Accumulation of } \\
\text { dysfunctional mitochondria; }\end{array}$ \\
\hline $\begin{array}{l}\text { Muratore et } \\
\text { al., } 2017 \\
{[191]}\end{array}$ & & & $\begin{array}{l}- \text { Generation of } A \beta \text { plaques and the responsiveness of TAU to A } \\
\text { affected by neuronal cell type; } \bullet \text { Rostral neurons more sensitive } \\
\text { than caudal neurons; }\end{array}$ \\
\hline $\begin{array}{l}\text { Ochalek et } \\
\text { al., } 2017 \\
\text { [192] }\end{array}$ & & $\begin{array}{l}\bullet \text { fAD PSEN1 V89L } \\
\text { •fAD PSEN1 L150P } \\
\text { •SAD }\end{array}$ & $\begin{array}{l}\text { - } A D \text { and SAD neurons increased extracellular } A \beta 40 \text { and } A \beta 42 \text {. } \\
\text { Significantly increased } A \beta 42: 40 \text { ratios were observed only in } \\
\text { samples of patients with } f A D ; \bullet \text { Increased levels of active GSK3 } \\
\text { and levels of APP synthesis and carboxy-terminal fragment } \\
\text { cleavage; • Elevated sensitivity to oxidative stress induced by } \\
\text { amyloid oligomers or peroxide detected in both fAD- and sAD- } \\
\text { derived neurons; }\end{array}$ \\
\hline $\begin{array}{l}\text { Ortiz- } \\
\text { Virumbrales } \\
\text { et al., } 2017 \\
\end{array}$ & $\begin{array}{l}\text { Basal } \\
\text { forebrain } \\
\text { cholinergi }\end{array}$ & - $f A D$ PSEN & $\begin{array}{l}- \text { Increase in the } A \beta 42 / 40 ;-A l t e r a t i o n \text { in electrophysiology: } \\
\text { neurons generated fewer maximum number of spikes in } \\
\text { response to a square depolarizing current injection; } \bullet \text { Decreased } \\
\text { height of the first action potential at rheobase current injection; }\end{array}$ \\
\hline $\begin{array}{l}\text { Birnbaum et } \\
\text { al., } 2018 \\
\text { [194] }\end{array}$ & $\begin{array}{l}\text { iNs (NGN2 } \\
\text { overexpre } \\
\text { ssion) }\end{array}$ & & $\begin{array}{l}\text {-Aberrant ROS production in AD patient iN cells does not } \\
\text { correlate with AB or P-TAU levels; } \bullet \text { High ROS levels correlate } \\
\text { with increased DNA damage; •Altered levels of oxphos } \\
\text { complexes found in AD patient-derived iN cells; •Synaptic } \\
\text { proteins are unaffected; }\end{array}$ \\
\hline $\begin{array}{l}\text { García-León } \\
\text { et al., } 2018 \\
{[93]}\end{array}$ & $\begin{array}{l}\text { Cortical } \\
\text { neurons }\end{array}$ & $\begin{array}{c}\cdot \text { Triple TAU mutant } \\
(N 279 K, P 301 L \text {, and } \\
E 10+16)\end{array}$ & $\begin{array}{l}\text {-Mutant neurons expressed pathogenic } 4 \mathrm{R} \text { and P-TAU, } \\
\text { endogenously triggered TAU aggregation, and had increased } \\
\text { electrophysiological activity; } \bullet \text { Deficiencies in neurite outgrowth, } \\
\text { aberrant sequence of differentiation to cortical neurons; } \\
\text {-Significant activation of the stress response; }\end{array}$ \\
\hline $\begin{array}{l}\text { Hu et al., } \\
2018[195]\end{array}$ & $\begin{array}{l}\text { Cortical } \\
\text { neurons }\end{array}$ & $\begin{array}{l}\text {-fAD PSEN1 } \\
\text { L113_I114insT } \\
\text {-fAD APP dup } \\
\text {-Down Syndrome } \\
\text { (extra copy of APP) }\end{array}$ & $\begin{array}{l}\text {-Assessed the ability of secretomes from iPSC-derived models of } \\
\text { AD to disrupt synaptic long-term potentiation when delivered to } \\
\text { the hippocampus of live adult rats; } \bullet \text { PSEN1 and APP mediated } \\
\text { synaptic dysfunction in rats via A } \beta \text { peptides, while trisomy } 21 \text { via } \\
\text { extracellular TAU; }\end{array}$ \\
\hline Li et al., 2018 & $\begin{array}{l}\text { Cortical } \\
\text { neurons }\end{array}$ & -fAD PSEN1 E120K & $\begin{array}{l}\bullet \text { Increased extracellular accumulation of } A \beta ; \bullet \text { High levels of P- } \\
\text { TAU; •Mitochondrial abnormalities; •Defective autophagy; }\end{array}$ \\
\hline $\begin{array}{l}\text { Moreno et } \\
\text { al., 2018 } \\
\text { [197] }\end{array}$ & $\begin{array}{l}\text { Basal } \\
\text { forebrain } \\
\text { cholinergi } \\
\text { c neurons }\end{array}$ & $S E I N \angle I$ & $\begin{array}{l}\text {-Assessed if the PSEN2 } \mathrm{N} 141 \mathrm{l} \text { mutation alters insulin signaling, } \\
\text { insulin regulation of the major AD proteins } A \beta \text { and/or TAU, } \\
\text { and/or calcium fluxes. Found that PSEN2 N141/ does not induce } \\
\text { neuronal insulin resistance; } \bullet \text { Insulin corrected calcium fluxes and }\end{array}$ \\
\hline
\end{tabular}


Table 1 (continued)

\begin{tabular}{|c|c|c|c|}
\hline & & & lowered $A \beta 42: 40$ ratio; \\
\hline $\begin{array}{l}\text { Ovchinnikov } \\
\text { et al., } 2018 \\
{[198]}\end{array}$ & Neurons & $\begin{array}{l}\text {-Down Syndrome } \\
\text { (extra copy of APP) } \\
\text {-Deletion of APP } \\
\text {-OE of APP in WT } \\
\text { iPSCS }\end{array}$ & $\begin{array}{l}\text {-Increased } A P P \text { gene dosage is responsible for increased } A \beta \\
\text { production, altered } A \beta 42 / 40 \text { ratio, and deposition of the } \\
\text { pyroglutamate (E3)-containing amyloid aggregates, but not for } \\
\text { several TAU-related } A D \text { phenotypes or increased apoptosis; } \\
\text {-Transcriptome comparisons showed that } A P P \text { has a widespread } \\
\text { impact on neuronal gene expression; }\end{array}$ \\
\hline $\begin{array}{l}\text { Robbins et } \\
\text { al., } 2018 \\
\text { [199] }\end{array}$ & $\begin{array}{l}\text { Cortical } \\
\text { neurons }\end{array}$ & $\begin{array}{l}\text { CRISPR/Cas9 } \\
\text { induced: } \\
\text {-CLUSTERIN-KO }\end{array}$ & $\begin{array}{l}\text {-Wild type neurons responded to } A \beta 42 \text { exposure by significantly } \\
\text { decreasing the neurite length; } \cdot C L U S T E R I N \text { KO neurons exposure } \\
\text { to } A \beta 42 \text { did not induce any effect; }\end{array}$ \\
\hline $\begin{array}{l}\text { Wang et al., } \\
2018 \text { [200] }\end{array}$ & Neurons & $\begin{array}{l}\text { Isogenic: } \\
-A P O E 3 \\
-A P O E 4 \\
-A P O E \text { null }\end{array}$ & $\begin{array}{l}-A P O E 4 \text { neurons have higher levels of P-TAU unrelated to their } \\
\text { increased } A \beta \text { production and displayed GABAergic neuron } \\
\text { degeneration; } \bullet A P O E 4 \text { increased A } A \text { production in human, but } \\
\text { not in mouse, neurons; - Treating APOE4 neurons with a small- } \\
\text { molecule structure corrector ameliorated the detrimental } \\
\text { effects; }\end{array}$ \\
\hline $\begin{array}{l}\text { Wezyk et al., } \\
2018[201]\end{array}$ & $\begin{array}{l}\text { Neurons } \\
\text { (Fibroblas } \\
\text { ts) }\end{array}$ & •fAD PSEN1 R307S & $\begin{array}{l}\text {-Overreactive BRCA1 (Ser1524) colocalized with degraded } \\
\text { PSEN1; •Increased level of P-Cdc25C (Ser216), resulted in cell } \\
\text { cycle re-entry-associated cell death; }\end{array}$ \\
\hline $\begin{array}{l}\text { Chang et al., } \\
2019 \text { [202] }\end{array}$ & Neurons & -fAD APP D678H & 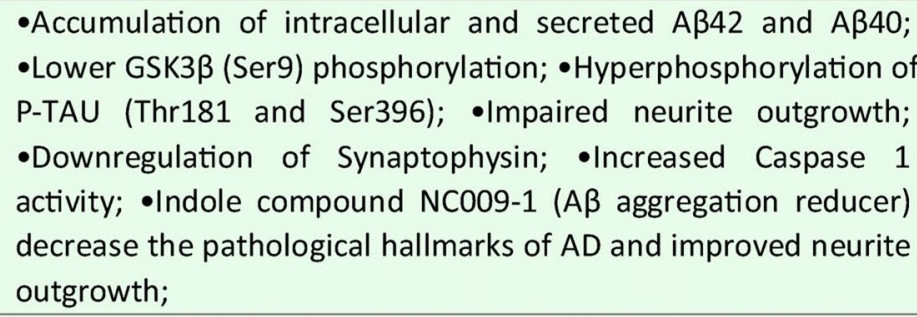 \\
\hline $\begin{array}{l}\text { Fang et al., } \\
2019 \text { [203] }\end{array}$ & $\begin{array}{l}\text { Cortical } \\
\text { neurons }\end{array}$ & $\begin{array}{l}\bullet A P P / V 717 L \\
\bullet A P O E 4 / 4\end{array}$ & $\begin{array}{l}\bullet \text { Normal autophagic flux, but reduced overall induction of the } \\
\text { autophagy pathway; } \bullet \text { Increased DNA damage; }\end{array}$ \\
\hline $\begin{array}{l}\text { Kwart et al., } \\
2019 \text { [204] }\end{array}$ & $\begin{array}{l}\text { Cortical } \\
\text { neurons }\end{array}$ & $\begin{array}{l}\text { CRISPR Knock-In: } \\
\text {-APP Swedish } \\
\text {-APP A692G } \\
\text {-APP V717G } \\
\text {-APP 673T (protective) } \\
\text {-APP-KO } \\
\text {-PSEN1 M146V } \\
\text {-PSEN1 L166P } \\
\text {-PSEN1 A246E } \\
\text {-PSEN1-null }\end{array}$ & $\begin{array}{l}- \text { Transcriptomic and translatomic analyses identified changes in } \\
A D \text { and endosomal genes; } \bullet A P P \text { and PSEN } 1 \text { mutations had } \\
\text { divergent effects on the processing of } A P P \text { and } A \beta \text { peptide } \\
\text { production, but they all resulted in accumulation of longer } A \beta \\
\text { species ( } A 343 \text { and/or } A \beta 42 \text { ) as well as of } \beta \text {-CTF; } \bullet \beta-C T F \text { mediated } \\
\text { endosomal dysfunction and early endosome enlargement, not } \\
A \beta \text { peptides; } \bullet \text { Rab5 early endosome enlargement is common in } \\
A P P \text { and PSEN1 mutant neurons and could be rescued by } \\
\text { inhibition of } \beta \text {-secretase }(B A C E) ;\end{array}$ \\
\hline $\begin{array}{l}\text { van der Kant } \\
\text { et al., } 2019 \\
\text { [205] }\end{array}$ & $\begin{array}{l}\text { Cortical } \\
\text { neurons }\end{array}$ & $\begin{array}{l}\text { - } A \text { AD APP dup } \\
\text {-SAD }\end{array}$ & $\begin{array}{l}\text { - Cholesteryl esters (CE), the storage product of excess } \\
\text { cholesterol, were identified as upstream regulators of P-TAU } \\
\text { proteostasis; -The effects of CE on TAU proteostasis are } \\
\text { correlated with, but independent of, APP and A } 3 \text {; -Lead } \\
\text { compound (CYP 46A1) enhance CE-dependent P-TAU } \\
\text { proteasomal turnover specifically in neurons; }\end{array}$ \\
\hline $\begin{array}{l}\text { Wadhwani } \\
\text { et al., } 2019 \\
\text { [206] }\end{array}$ & $\begin{array}{l}\text { Forebrain } \\
\text { excitatory } \\
\text { neurons }\end{array}$ & $\begin{array}{l}-S A D A P O E 4 / 4 \\
\text { corrected to } E 3 / 3\end{array}$ & $\begin{array}{l}\text {-Increased cell death in APOE4/4 neurons; } \bullet \text { Increased P-TAU } \\
\text { and ERK1/2 phosphoactivation; •Increased secretion of } \\
\text { P-TAU via heparin sulfate proteoglycan- } \\
\text { dependent mechanism; }\end{array}$ \\
\hline
\end{tabular}


Table 1 (continued)

\begin{tabular}{|c|c|c|c|}
\hline $\begin{array}{l}\text { Arber et al., } \\
2020[207]\end{array}$ & Neurons & $\begin{array}{l}\text {-fAD APP V717I } \\
\text {-fAD PSEN1 int4del } \\
\text {-fAD PSEN1 Y115H } \\
\text {-fAD PSEN1 M139V } \\
\text {-fAD PSEN1 R278I }\end{array}$ & $\begin{array}{l}\text {-Increased } A \beta 42: 40 \text { ratio relative to controls with varied } \\
\text { signatures for } A \beta 43, A \beta 38 \text {, and short } A \beta \text { fragments; } \bullet A P P V 717 I \\
\text { mutations alter } \gamma \text {-secretase cleavage site preference; } \bullet \text { Distinct } \\
\text { PSEN1 mutations lead to reduced } \gamma \text {-secretase carboxypeptidase- } \\
\text { like activity; } \bullet \text { Proposed four qualitatively distinct mechanisms } \\
\text { behind raised } A \beta 42: 40 \text { ratio: }(1) A P P \text { V717I mutations alter } \gamma \text { - } \\
\text { secretase cleavage site preference, whereas distinct PSEN1 } \\
\text { mutations lead to either }(2) \text { reduced } \gamma \text {-secretase activity, (3) } \\
\text { altered protein stability or }(4) \text { reduced PSEN1 maturation, all } \\
\text { culminating in reduced } \gamma \text {-secretase carboxypeptidase-like } \\
\text { activity; }\end{array}$ \\
\hline \multirow{2}{*}{$\begin{array}{l}\text { Knupp et al., } \\
2020[154]\end{array}$} & & \multirow[b]{2}{*}{ •SORL1 KO } & \multirow{2}{*}{$\begin{array}{l}\text {-Enlarged early endosomes; •Altered APP trafficking and } \\
\text { processing in the endosomal network; } \bullet \text { No effect on endosomes } \\
\text { in microglia; }\end{array}$} \\
\hline & Microglia & & \\
\hline $\begin{array}{l}\text { Langness et } \\
\text { al., } 2020 \\
{[208]}\end{array}$ & Neurons & $\begin{array}{l}\text {-fAD PSEN1 L286V } \\
\text { •fAD PSEN1 R278I }\end{array}$ & $\begin{array}{l}\text {-The ratio of APP isoforms (130:110kDa) and mature ADAM } 10 \\
\text { was significantly reduced in PSEN1 gene mutations compared to } \\
\text { control; -Distinct phenotype for both mutations observed, } \\
\text { including } A \beta 42: 40 \text { ratio, increase in } A \beta 40 \text { and } A \beta 42 \text {, antioxidant } \\
\text { status and markers of protein carbonylation and lipid } \\
\text { peroxidation; }\end{array}$ \\
\hline $\begin{array}{l}\text { Martins et } \\
\text { al., } 2020\end{array}$ & ns & $7 H$ & $\begin{array}{l}\text {-AD neuronal cultures showed altered metabolic pathways, } \\
\text { phagosome, immune response, and protein processing in the ER; }\end{array}$ \\
\hline $\begin{array}{l}\text { Arber et al., } \\
2021[210]\end{array}$ & Organoids & $\begin{array}{l}\text {-fAD APP V717I } \\
\text {-fAD PSEN1 int4del } \\
\text {-fAD PSEN1 Y115H } \\
\text {-fAD PSEN1 M139V } \\
\text {-fAD PSEN1 R278I }\end{array}$ & $\begin{array}{l}- \text { Familial Alzheimer's disease mutations in PSEN1 cause } \\
\text { premature neurogenesis with PSEN1 int4del and } Y 115 H \text { having } \\
\text { the strongest phenotype; } \bullet V 717 / \text { mutation in } A P P \text { may increase } \\
\text { total neurogenesis; }\end{array}$ \\
\hline $\begin{array}{l}\text { Elsworthy et } \\
\text { al., } 2021 \\
{[211]}\end{array}$ & Neurons & $\begin{array}{l}\text {-fAD PSEN1 L286V } \\
\text {-fAD PSEN1 R278I }\end{array}$ & $\bullet$ Altered APP processing; •Elevated oxidative stress; \\
\hline $\begin{array}{l}\text { Mertens et } \\
\text { al., } 2021 \\
{[212]}\end{array}$ & $\begin{array}{l}\text { Induced } \\
\text { Neurons } \\
\text { (iNs) } \\
\text { iPSC- } \\
\text { derived } \\
\text { iNs }\end{array}$ & $\begin{array}{l}16 \text { AD subjects: } \\
\text { - sAD ( } n=13) \\
\text {-fAD ( } n=3 ; \text { APP and } \\
\quad \text { PSEN } 1)\end{array}$ & $\begin{array}{l}\text { - iNs from the familial } A D \text { patients showed increased } A B 42: 40 \\
\text { ratios; - bulk mRNA seq results showed functional neuronal } \\
\text { failure, stress response, and cell cycle re-entry; }-A D \text { iN cultures } \\
\text { displayed less complex dendritic morphologies, reduced } \\
\text { synapsin/PSD-95 co-labeled synapse-like structures and a } \\
\text { reduced frequency of Ca2+ neuronal activity but no signs of } \\
\text { increased neuronal cell death; • AD iNs showed higher similarity } \\
\text { to immature stages resembling a process of de-differentiation in } \\
\text { response to injury; }\end{array}$ \\
\hline $\begin{array}{l}\text { Jones et al., } \\
2017 \text { [168] }\end{array}$ & NPCS & $\begin{array}{l}\text {-fAD PSEN1 M146L } \\
\text { •SAD APOE4/4 }\end{array}$ & $\begin{array}{l}\text { - Induced astrocytes have pronounced pathological phenotype, } \\
\text { less complex morphology, and abnormal localization of key } \\
\text { functional astroglial markers (decreased S100B, EAAT1 and GS, } \\
\text { morphology changes and cytosolic distribution of S100B); •NPCs } \\
\text { derived from identical patients did not show any differences; }\end{array}$ \\
\hline $\begin{array}{l}\text { Oksanen et } \\
\text { al., } 2017[73]\end{array}$ & Astrocytes & $\begin{array}{l}\bullet \text { Isogenic PSEN1 } \\
\qquad \triangle E 9\end{array}$ & $\begin{array}{l}\bullet \text { Increased } \mathrm{A} \beta \text { production and oxidative stress; } \bullet \text { Altered } \\
\text { cytokine release and } \mathrm{Ca}^{2+} \text { homeostasis; } \bullet \text { Reduced neuronal } \\
\text { support function in PSEN1 astrocytes; }\end{array}$ \\
\hline $\begin{array}{l}\text { Zhao et al., } \\
2017 \text { [74] }\end{array}$ & Astrocytes & $\begin{array}{l}-A P O E 4 / 4 \\
-A P O E 3 / 3\end{array}$ & $\begin{array}{l}\text {-Astrocytes secreted abundant APOE with APOE4 lipoprotein } \\
\text { particles less lipidated compared to APOE3; •APOE4/4 }\end{array}$ \\
\hline
\end{tabular}


Table 1 (continued)

astrocytes less effectively support neuronal survival and synaptogenesis;

\begin{tabular}{|c|c|c|c|}
\hline $\begin{array}{l}\text { Fong et al., } \\
2018 \text { [213] }\end{array}$ & Astrocytes & -APP KO & $\begin{array}{l}\text { - Full-length APP regulates lipoprotein metabolism and A } \beta \\
\text { clearance; •Reduced cholesterol and elevated expression of a } \\
\text { regulatory element-binding protein (SREBP); •Reduced } \\
\text { lipoprotein endocytosis; }\end{array}$ \\
\hline $\begin{array}{l}\text { Konttinen et } \\
\text { al., } 2019 \\
{[214]}\end{array}$ & Astrocytes & -fAD PSEN1 $\triangle E 9$ & $\begin{array}{l}\text {-Impaired fatty acid oxidation; } \bullet \text { Rescued by synthetic } \\
\text { peroxisome proliferation activated receptor delta }(P P A R \beta / \delta) \\
\text { agonist GW0742; }\end{array}$ \\
\hline $\begin{array}{l}\text { Sienski et al., } \\
2021[215]\end{array}$ & Astrocytes & $\begin{array}{l}\text {-Isogenic APOE4/4 } \\
\text { and APOE3/3 }\end{array}$ & $\begin{array}{l}\text {-APOE4 astrocytes accumulate unsaturated triglycerides leading } \\
\text { to a lipid imbalance; } \bullet \text { Choline supplementation restored lipid } \\
\text { homeostasis; }\end{array}$ \\
\hline $\begin{array}{l}\text { Abud et al., } \\
2017[114]\end{array}$ & $\begin{array}{l}\text { Induced } \\
\text { Microglia } \\
\text { (iMGLs) }\end{array}$ & •Healthy individual & $\begin{array}{l}\text {-iMGLs internalize fluorescently labeled fibrillar } A \beta(f A \beta) \text {; } \\
\text {-recognized and internalized brain-derived TAU oligomers } \\
\text { (BDTOs) to the acidic lysosomal compartment; }\end{array}$ \\
\hline $\begin{array}{l}\text { Claes et al., } \\
2019[216]\end{array}$ & $\begin{array}{l}\text { Transfdiff } \\
\text { erentiated } \\
\text { Microglia } \\
\text { (tMGs) }\end{array}$ & $\begin{array}{l}-T R E M 2+/ R 47 H \\
-T R E M 2+/- \\
\text {-TREM2-/- }\end{array}$ & $\begin{array}{l}- \text { TREM } 2+/- \text { and TREM2-/- tMGs phagocytosed less E. coli } \\
\text { fragments and cleared fewer amyloid plaques than wild-type } \\
\text { hPSC progeny, with no difference for TREM } 2+/ R 47 H \text { progeny; }\end{array}$ \\
\hline $\begin{array}{l}\text { Konttinen et } \\
\text { al., } 2019 \\
{[217]}\end{array}$ & $\begin{array}{l}\text { Induced } \\
\text { Microglia } \\
\text { (iMGLs) }\end{array}$ & $\begin{array}{l}\text {-fAD APP SWe } \\
\text {-fAD PSEN1 } 1 E 9 \\
\text {-APOE4/4 }\end{array}$ & $\begin{array}{l}\text {-APOE4 genotype impairs phagocytosis, migration, metabolic } \\
\text { activity of iMGLs and their cytokine secretion; }\end{array}$ \\
\hline $\begin{array}{l}\text { Xu et al., } \\
2019[218]\end{array}$ & $\begin{array}{l}\text { Induced } \\
\text { Microglia } \\
\text { (iMGLs) }\end{array}$ & -sAD & $\begin{array}{l}\text { - AD-iMGLs have the stronger phagocytic ability, and } \\
\text { inflammatory characteristics; • High LPS concentrations caused } \\
\text { death in control iMGLs; } \bullet \text { TNF- } \alpha \text {, IL- } 6 \text {, and IL-10 secreted by AD- } \\
\text { iMGLs increased upon LPS stimulation; }\end{array}$ \\
\hline $\begin{array}{l}\text { Raja et al., } \\
2016[219]\end{array}$ & Organoids & $\begin{array}{l}\text {-fAD APP dup } \\
\text {-fAD PSEN1 M146I } \\
\text {-fAD PSEN2 A264E }\end{array}$ & $\begin{array}{l}\text {-Amyloid aggregation; •Hyperphosphorylated TAU protein; } \\
\text {-Endosome abnormalities; }\end{array}$ \\
\hline $\begin{array}{l}\text { Lin et al., } \\
2018[220]\end{array}$ & $\begin{array}{l}\text { Neurons } \\
\text { Astrocytes } \\
\text { Microglia } \\
\text { Organoids }\end{array}$ & $\begin{array}{l}-S A D / \text { Healthy } \\
\text { individual }\end{array}$ & $\begin{array}{l}- \text { Impaired } A \beta \text { clearance and increased cholesterol content of } \\
\text { APOE4 astrocytes; } \bullet \text { Reduced morphological complexity of } \\
\text { APOE4 microglia; } \bullet \text { Reduced } A \beta \text { uptake from media by fAD } \\
\text { organoids; }\end{array}$ \\
\hline $\begin{array}{l}\text { Gonzalez et } \\
\text { al., } 2018 \\
{[221]}\end{array}$ & Organoids & $\begin{array}{l}\text {-fAD PSEN1 A246E } \\
\text {-Down Syndrome } \\
\text { (extra copy of APP) }\end{array}$ & $\begin{array}{l}\text {-Treatment of patient-derived organoids with } \beta \text { - and } \gamma \text {-secretase } \\
\text { inhibitors significantly reduced amyloid and TAU pathology; }\end{array}$ \\
\hline $\begin{array}{l}\text { Pavoni et al., } \\
2018[222]\end{array}$ & Organoids & •Healthy individual & -Induction of $A \beta$ accumulation by Aftin-5; \\
\hline $\begin{array}{l}\text { Zhao et al., } \\
2020[223]\end{array}$ & Organoids & $\begin{array}{l}\text {-sAD/ Healthy } \\
\text { individual }\end{array}$ & -Synapse loss and neurodegeneration; \\
\hline $\begin{array}{l}\text { Alić et al., } \\
2020 \text { [224] }\end{array}$ & Organoids & $\begin{array}{l}\text {-Down Syndrome } \\
\text { (extra copy of APP) }\end{array}$ & $\begin{array}{l}\text { - Extracellular diffuse and fibrillar A } 3 \text { deposits; } \\
\text {-Hyperphosphorylated/ pathologically conformed TAU and } \\
\text { premature neuronal loss; •Presence/absence of AD-like } \\
\text { pathology was donor-specific; } \bullet \text { Pathology could be triggered by } \\
\text { the elimination of the third copy of chromosome } 21 \text { gene BACE2 } \\
\text { but prevented by combined chemical } \beta \text { and } \gamma \text {-secretase } \\
\text { inhibition; }\end{array}$ \\
\hline Hernández & Organoids & -SAD APOE3/3 & -Variation in pathological hallmarks (AB and P-TAU) in six- \\
\hline
\end{tabular}


Table 1 (continued)

\begin{tabular}{|c|c|c|c|}
\hline $\begin{array}{l}\text { et al. } 2021 \\
\text { [225] }\end{array}$ & & $\begin{array}{l}\text { - } \mathrm{SAD} \text { APOE4/4 } \\
\text {-Isogenic APOE3 } \\
\text { and APOE4 }\end{array}$ & $\begin{array}{l}\text { month-old cerebral organoids mostly independent of the APOE } \\
\text { allele but associated with the high variability of differentiation; } \\
\text { - Conversion of APOE4 into APOE3 led to decreased P-TAU } \\
\text { (Ser199), with no changes to Ser396 and Thr231; }\end{array}$ \\
\hline $\begin{array}{l}\text { Park et al., } \\
2021 \text { [226] }\end{array}$ & Organoids & $\begin{array}{l}\text { - sAD/ Healthy } \\
\text { individual }(\mathrm{n}=11) \\
\text {-Isogenic APOE3, } \\
\text { APOE4 }\end{array}$ & $\begin{array}{l}\bullet \text { Increased levels of A } \beta \text { and P-TAU; } \bullet \text { Developed network-based } \\
\text { high-content drug-screening platform; } \bullet \text { Integrated mathematical } \\
\text { modeling and the pathological features of AD with human iPSC- } \\
\text { derived cerebral organoids; }\end{array}$ \\
\hline
\end{tabular}

effectiveness of DNA repair processes [183, 200]. Similarly, Ortiz-Virumbrales et al. observed altered electrophysiology of neuronal cells in case of an increased A $\beta 42 / 40$ ratio [179]. Additionally, neuronal toxicity and disrupted functionality can also be obtained by exogenous $\mathrm{A} \beta$ administration [198, 201]. Notably, these exogenous $A \beta$ oligomers preferentially induced toxicity in glutamatergic neurons compared to GABAergic neurons [202]. Lastly, studies also showed that fAD neurons (PSEN1 ${ }^{A 246 E}$; PSEN1 ${ }^{\text {L150P }}$ ) were more susceptible to $\mathrm{A} \beta 42$ than neurons derived from sAD patients or healthy controls [203, 204].

Interestingly, what emerges from recent studies of AD-iPSC-derived neurons is that the lipid and cholesterol metabolism and the intracellular trafficking defects may be an important common pathological process associated with AD and other neurodegenerative diseases [189, 205, 206]. A recent study by van der Kant showed that cholesteryl esters (CE), the storage product of excess cholesterol, are upstream regulators of P-TAU proteostasis and are independent of APP and A $\beta$ [189]. Several other studies then investigated early endosomal-related defects in fAD [191, 193, 194], and a recent comprehensive iPSC-based study [185] suggests the presence of early endosome enlargement as a potentially unifying pathological hallmark of AD. Moreover, their RNAseq analysis and ribosome profiling found multiple common endocytic/endosomal trafficking-associated genes dysregulated in all analyzed fAD mutant neurons (i.e., APP-Swe, APP-A692G, APP-V717G, PSEN1-M146V, PSEN1-L166P, PSEN1-A246E, APP-KO, and PSEN1-null). Many of these trafficking-related genes have been previously implicated in late-onset AD (e.g., SORL1, CLU, APOE, etc.). This, therefore, suggests that a shared network of cellular and molecular changes may underlie both SAD and fAD pathogenesis [185].

Additionally, it is of note that neurodifferentiation models based on pluripotent iPSCs and/or direct reprogramming techniques are beneficial to address the differentiation propensity of disease-relevant cell types. Curiously, experiments on AD neurons are now showing somewhat contradictory results. On the one hand, several robustly designed studies bring evidence that neurons derived from both sAD and fAD(PSEN1)-iPSCs differentiate prematurely [170, 171, 207]. On the contrary, a new publication by Mertens et al. very clearly shows that neurons induced directly from AD patient's fibroblasts lack fully differentiated phenotype and have downregulated genes related to synaptic transmission, ion transport, and synaptic plasticity [180]. Thus, this study opens several interesting questions, including whether neuronal changes in $\mathrm{AD}$ result from the accumulation of damaging agents or rather a lack of a fully differentiated neuronal transcription. They also hypothesize that this "hypo-mature" state of AD-induced neurons might relate to the fundamental cell biological process of de-differentiation in response to injury [180].

\section{Astrocytes}

In $\mathrm{AD}$, astrocytes were shown to undergo initial atrophy with subsequent reactive astrocytic hypertrophy ([208] and reviewed by [209]). Both processes are thought to be accelerated by an astrocytic reaction to $A \beta$ fragments in their vicinity [210, 211].

Several iPSCs derived fAD $[73,169,212]$ and sAD [70, $74,205]$ astrocyte models have been reported thus far (see Table 1 for details). In the case of fAD, Oksanen et al. demonstrated that fAD PSEN1 E9 astrocytes show an increased release of $\mathrm{A} \beta 42$, cytokine profile dysregulation, altered $\mathrm{Ca}^{2+}$ homeostasis, increased ROS, and decreased lactate production [73]. Fong et al. reported that APP-KO astrocytes show reduced cholesterol levels and an elevated expression of the regulatory element-binding protein (SREBP), which are both downstream consequences of reduced lipoprotein endocytosis [212]. Jones et al. (2017) further showed that induced astrocytes derived from both SAD and fAD (PSEN1 M146L) patients exhibit a pronounced pathological phenotype. They showed significantly less complex morphological appearance, overall atrophic profiles, and abnormal localization of key functional astroglial markers (no glial fibrillary acidic protein (GFAP) changes but decreased S100B, EAAT1, and GS, morphology changes, and cytosolic distribution of S100B) [169]. Studies on sAD-iPSC-derived astrocytes additionally show APOE4/4 astrocytes less effectively 
support neuronal survival and synaptogenesis and that the astrocytes secrete abundant APOE with APOE4 lipoprotein particles less lipidated compared to APOE3 [74]. Lastly, Lin et al. (2018) showed impaired $A \beta$ clearance and increased cholesterol content of APOE4 astrocytes [213], and a new study by Sienski et al. reveals disrupted intracellular lipid homeostasis in both astrocytes and microglia [205]. Overall, elucidating disease-specific cellular responses in astrocytopathies may be a crucial factor in AD progression and manifestation.

\section{Oligodendrocytes}

Oligodendrocytes generate myelin sheaths around axons. However, it has been shown that a subset of proliferative, immature oligodendrocytes may play a role in neural repair [214]. Studies related to AD showed that the morphology of oligodendrocytes is altered in $\mathrm{AD}$ [215]. Additionally, $\mathrm{A} \beta$ oligomers caused a decrease in myelin proteins [216] and were toxic to oligodendrocytes [217]. And while oligodendrocytes have been successfully generated from iPSCs [104, 218, 219], the assessment of the role they may play in $\mathrm{AD}$ and their relevance in $\mathrm{SAD}$ models have, as yet, not been reported [166].

\section{Microglia}

Neuroinflammation is implied as one of the defining features of neurodegenerative diseases. Under these pathological conditions, microglia adopt a reactive state with morphological and functional changes [220]. In AD, the first evidence of reactive microglia in neuritic plaques was described by Alois Alzheimer himself [221]. Reactive glial cells have been since documented in numerous other studies [222], where they cluster around $A \beta$ plaques highlighting their inability to clear $\mathrm{A} \beta[223,224]$. Microglia are also implicated in the neuroinflammatory component of AD etiology, including cytokine/chemokine secretion, which worsens disease pathology [225]. The microglial reaction was considered only incidental and rather a functional response of microglia to the deposition of $A \beta$ and neuritic plaques formation. However, recent genome-wide association studies identified several high-risk AD loci genes, namely TREM2 [226], Sp1, CD33 [227]. These genes are highly or even exclusively expressed in microglia, suggesting that microglial might be crucially involved in the initial causal pathogenesis of AD [228].

iPSCs-derived microglia (see Table 1 for details) manifested the ability to phagocyte AD-related substances, including $\beta$-amyloid and Tau oligomers [114]. Moreover, once exposed to fibrilar $A \beta$, microglial cells expressed different gene expression profiles with a predominant increase among microglial AD risk genes [114]. In another study,
AD-iPSCs microglia displayed higher phagocytic ability with limited cellular death upon lipopolysaccharide exposure compared to wild-type microglia [229]. Recent studies also examined the role of the APOE4 allele in microglial cells. Generation of APOE4/4 microglial cells led to significant dysregulation of gene expression levels and reduced $\mathrm{A} \beta$ internalization [213]. Moreover, Lin et al. applied his concept of APOE4/4 microglia and APOE $3 / 3$ microglia to study the ability to internalize $\mathrm{A} \beta$ peptides from diffusely $\mathrm{A} \beta$ affected 3D organoids. APOE3/3 microglial cells had higher activity of phagocytosis compared to APOE4/4. Comparatively to $A P O E 4$, additional studies with microglia-associated AD-risk factors, i.e., TREM2 [230], were conducted to validate the feasibility of $\mathrm{AD}$ modeling using the iPSCs microglial models.

\section{D Models}

While 2D cellular models of Alzheimer's disease significantly expanded our understanding of $\mathrm{AD}$, it has become apparent that more complex models will be needed to examine (1) the interaction between multiple cell types connected to AD pathogenesis; (2) complex 3D transcriptomics; (3) role of immune cells; (4) organization of neuronal populations; and (5) formation of neurofibrillary tangles and plaques in the complex tissue-like environment. This absence of cerebral complexity in 2D cell cultures has been recently overcome by developing $3 \mathrm{D}$ cerebral organoids from hESCs [142]. Cerebral organoids recapitulated with a remarkable degree of detail human CNS development and proved to be an excellent tool for disease modeling, including $\operatorname{AD}[171,181,207,213,231-236]$. Initially, a 3D model of human neural stem cells overexpressing mutant PSEN1 and APP has been reported by Choi et al. [237]. This system was based on the culture of neural progenitor (ReN) cells in a thick layer of the extracellular matrix. Cells were genetically engineered to carry an AD-causing mutation in APP or PSEN1, and upon terminal differentiation, amyloid plaque-like and neurofibrillary tangle-like structures were observed. Functional studies showed that gamma-secretase inhibition reduced $\mathrm{A} \beta$ formation and led to a decrease in the P-Tau level [237].

Since this initial 3D model study of AD, ten publications described the generation of cerebral organoids from both fAD or SAD iPSCs and from the patient with Down syndrome (see Table 1 for details). These publications report increased $A \beta$ production, formation of $A \beta$ oligomer aggregates, increased Tau phosphorylation, synaptic loss, and endosomal abnormalities [171, 213, 231, 232, 234, 235]. Raja et al., as a first one, demonstrated that $3 \mathrm{D}$ AD cerebral organoids exhibit an increased $A \beta 42 / A \beta 40$ ratio, which is considered one of the most specific biomarkers for AD. Following treatment of AD cerebral organoids by a 
$\gamma$-secretase inhibitor and $\beta$-secretase inhibitor significantly reduced the propensity of $\beta$-amyloid accumulation and Tau phosphorylation [234]. Interestingly, a new study by Arber et al. additionally reports that selected PSEN1 mutations may cause premature neurogenesis confirming their data from 2D neurons [207]. Additionally, another study utilized a small-molecule approach to induce $\beta$-amyloid aggregation posttranslationally by Aftin-5 treatment [233]. Here, the potential was extended to non-AD cell lines with $\mathrm{A} \beta$ shift towards $A \beta 42$ production. Hence ideal for studying environmental factors contributing to $\mathrm{AD}$ etiopathogenesis.

Interestingly, a recent report shows evidence of innate microglia in developing cerebral organoids [238]. Following several publications embellishing the proof of a variety of macroglia that 3D cerebral organoids display [239, 240], a sophisticated approach in studying AD cellular interaction in $3 \mathrm{D}$ can be adapted. However, the complexity with limited vasculature [7, 241], fetal-transcriptome [242], relative lack of active synapses [232], and low-reproducibility [236] will be needed to be addressed in the future. Still, despite these limitations, 3D cerebral organoids have demonstrated in the last few years to be a powerful toolbox with the unique potential to explore novel therapeutic and genetic targets of $\mathrm{AD}$.

\section{Conclusions}

Taken together, iPSC-based models of AD have, thus far, provided numerous clues on molecular mechanisms that precede the development of $\mathrm{AD}$ pathology or confirmed those obtained from other model systems. While most of the studies focused on studying the AD-affected neurons, essential data was also acquired from investigations that focused on neural stem cells, glia, and cerebral organoids. Most importantly, the ability of these in vitro cultures to react to drug treatment provides hope that these models will be relevant on the way to finding a much-needed Alzheimer's disease-modifying drug treatment. Finally, possible combination of iPSC-based models with various other approaches (i.e., in vitro models, in vivo models, medical imaging, biomedical markers) regarding their biological, genetic, and pathological similarities opens the door to further improve our understanding of Alzheimer's disease.

Acknowledgements Authors would like to acknowledge Assoc. Prof. Ales Hampl for support and helpful discussions.

Author Contributions Writing-original draft preparation and literature search: Martin Barak, Veronika Fedorova, Veronika Pospisilova, Jan Raska, Jiri Sedmik, Simona Vochyanova, Tereza Vanova, Dasa Bohaciakova; writing-review, editing and critical revision: Hana Hribkova, Hana Klimova, Dasa Bohaciakova; funding acquisition: Dasa Bohaciakova, Jan Raska. All authors read and approved the final manuscript.
Funding This research was funded by the Czech Science Foundation (GACR; no. 18-25429Y, and 21-21510S), by AZV (no. NV19-0800472 and NU21-08-00373), by the European Regional Development Fund-Project INBIO (No. CZ.02.1.01/0.0/0.0/16_026/0008451), by the project ,SORLA-FIX “ no. 8F20009 of the Ministry of Education, Youth and Sports of the Czech Republic and EU Joint ProgrammeNeurodegenerative Disease Research, by the National Program of Sustainability II by the Ministry of education, Youth, and Sports of the Czech Republic (project no. LQ1605) and by Grant Agency of Masaryk University (GAMU; MUNI/G/1131/2017, MUNI/A/1382/2019 and MUNI/11/SUP/19/2020). DB was supported by funds from NF Neuron, Alzheimer NF, and by Career Restart Grant (MUNI/R/1697/2020). JR was supported by funds from Medical Faculty MU to Junior researcher (ROZV/25/LF/2019, ROZV/24/LF/2020). VF was supported by JCMM - PhD Talent. MB was supported by JCMM - Open Science. Figures were created with BioRender.com.

Data availability Not applicable.

Code availability Not applicable.

\section{Declarations}

Conflicts of Interest The authors declare no conflict of interest

Ethics approval Not applicable.

Consent to participate Not applicable.

Consent for publication Not applicable.

Open Access This article is licensed under a Creative Commons Attribution 4.0 International License, which permits use, sharing, adaptation, distribution and reproduction in any medium or format, as long as you give appropriate credit to the original author(s) and the source, provide a link to the Creative Commons licence, and indicate if changes were made. The images or other third party material in this article are included in the article's Creative Commons licence, unless indicated otherwise in a credit line to the material. If material is not included in the article's Creative Commons licence and your intended use is not permitted by statutory regulation or exceeds the permitted use, you will need to obtain permission directly from the copyright holder. To view a copy of this licence, visit http://creativecommons.org/licenses/by/4.0/.

\section{References}

1. Briscoe, J., \& Novitch, B. G. (2008). Regulatory pathways linking progenitor patterning, cell fates and neurogenesis in the ventral neural tube. Philosophical Transactions of the Royal Society B: Biological Sciences, 363(1489), 57-70. https://doi.org/10. 1098/rstb.2006.2012

2. Tiberi, L., Vanderhaeghen, P., \& van den Ameele, J. (2012). Cortical neurogenesis and morphogens: Diversity of cues, sources and functions. Current Opinion in Cell Biology, 24(2), 269-276. https://doi.org/10.1016/j.ceb.2012.01.010

3. Lowery, L. A., \& Sive, H. (2004). Strategies of vertebrate neurulation and a re-evaluation of teleost neural tube formation. Mechanisms of Development, 121(10), 1189-1197. https://doi. org/10.1016/j.mod.2004.04.022

4. Brüstle, O., \& McKay, R. D. (1996). Neuronal progenitors as tools for cell replacement in the nervous system. Current opinion in neurobiology, 6(5), 688-695. 
5. Gage, F. H. (2000). Mammalian neural stem cells. Science (New York, N.Y.), 287(5457), 1433-1438.

6. Temple, S. (2001). The development of neural stem cells. Nature, 414(6859), 112-117. https://doi.org/10.1038/35102174

7. Kelava, I., \& Lancaster, M. A. (2016). Dishing out mini-brains: Current progress and future prospects in brain organoid research. Developmental Biology, 420(2), 199-209. https://doi.org/10. 1016/j.ydbio.2016.06.037

8. Spemann, H. (1938). Embryonic development and induction. London, H. Milford, Oxford University Press.

9. Saxén, L. (1978). Two-gradient hypothesis of primary embryonic induction. Medical Biology, 56(6), 293-298.

10. Smith, W. C., \& Harland, R. M. (1992). Expression cloning of noggin, a new dorsalizing factor localized to the Spemann organizer in Xenopus embryos. Cell, 70(5), 829-840. https://doi.org/ 10.1016/0092-8674(92)90316-5

11. Hemmati-Brivanlou, A., Kelly, O. G., \& Melton, D. A. (1994). Follistatin, an antagonist of activin, is expressed in the Spemann organizer and displays direct neuralizing activity. Cell, 77(2), 283-295. https://doi.org/10.1016/0092-8674(94)90320-4

12. Sasai, Y., Lu, B., Steinbeisser, H., \& De Robertis, E. M. (1995). Regulation of neural induction by the Chd and Bmp-4 antagonistic patterning signals in Xenopus. Nature, 376(6538), 333-336. https://doi.org/10.1038/376333a0

13. Muñoz-Sanjuán, I., \& Brivanlou, A. H. (2002). Neural induction, the default model and embryonic stem cells. Nature Reviews Neuroscience, 3(4), 271-280. https://doi.org/10.1038/nrn786

14. Bain, G., Ray, W. J., Yao, M., \& Gottlieb, D. I. (1996). Retinoic acid promotes neural and represses mesodermal gene expression in mouse embryonic stem cells in culture. Biochemical and biophysical research communications, 223(3), 691-694. https:// doi.org/10.1006/bbrc.1996.0957

15. Okabe, S., Forsberg-Nilsson, K., Spiro, A. C., Segal, M., \& McKay, R. D. (1996). Development of neuronal precursor cells and functional postmitotic neurons from embryonic stem cells in vitro. Mechanisms of development, 59(1), 89-102.

16. Kawasaki, H., Mizuseki, K., Nishikawa, S., Kaneko, S., Kuwana, Y., Nakanishi, S., ... Sasai, Y. (2000). Induction of midbrain dopaminergic neurons from ES cells by stromal cell-derived inducing activity. Neuron, 28(1), 31-40.

17. Bohaciakova, D., Hruska-Plochan, M., Tsunemoto, R., Gifford, W. D., Driscoll, S. P., Glenn, T. D., ... Marsala, M. (2019). A scalable solution for isolating human multipotent clinical-grade neural stem cells from ES precursors. Stem Cell Research \& Therapy, 10(1), 83. https://doi.org/10.1186/s13287-019-1163-7

18. Elkabetz, Y., Panagiotakos, G., Al Shamy, G., Socci, N. D., Tabar, V., \& Studer, L. (2008). Human ES cell-derived neural rosettes reveal a functionally distinct early neural stem cell stage. Genes \& development, 22(2), 152-165. https://doi.org/ 10.1101/gad.1616208

19. Koch, P., Opitz, T., Steinbeck, J. A., Ladewig, J., \& Brüstle, O. (2009). A rosette-type, self-renewing human ES cell-derived neural stem cell with potential for in vitro instruction and synaptic integration. Proceedings of the National Academy of Sciences of the United States of America, 106(9), 3225-3230. https://doi.org/10.1073/pnas.0808387106

20. Zhang, S. C., Wernig, M., Duncan, I. D., Brüstle, O., \& Thomson, J. A. (2001). In vitro differentiation of transplantable neural precursors from human embryonic stem cells. Nature biotechnology, 19(12), 1129-1133. https://doi.org/10.1038/nbt12 01-1129

21. Fedorova, V., Vanova, T., Elrefae, L., Pospisil, J., Petrasova, M., Kolajova, V., ... Bohaciakova, D. (2019). Differentiation of neural rosettes from human pluripotent stem cells in vitro is sequentially regulated on a molecular level and accomplished by the mechanism reminiscent of secondary neurulation. Stem Cell Research, 40, 101563. https://doi.org/10.1016/j.scr.2019.101563

22. Grabiec, M., Hř́ibková, H., Vařecha, M., Stř́tecká, D., Hampl, A., Dvořák, P., \& Sun, Y.-M. (2016). Stage-specific roles of FGF2 signaling in human neural development. Stem Cell Research, 17(2), 330-341. https://doi.org/10.1016/j.scr.2016.08.012

23. Hř́́bková, H., Grabiec, M., Klemová, D., Slaninová, I., \& Sun, Y.-M. (2018). Calcium signaling mediates five types of cell morphological changes to form neural rosettes. Journal of Cell Science, 131(3). https://doi.org/10.1242/jcs.206896

24. Falk, A., Koch, P., Kesavan, J., Takashima, Y., Ladewig, J., Alexander, M., ... Brüstle, O. (2012). Capture of neuroepithelial-like stem cells from pluripotent stem cells provides a versatile system for in vitro production of human neurons. PloS One, 7(1), e29597. https://doi.org/10.1371/journal.pone.0029597

25. Chambers, S. M., Fasano, C. A., Papapetrou, E. P., Tomishima, M., Sadelain, M., \& Studer, L. (2009). Highly efficient neural conversion of human ES and iPS cells by dual inhibition of SMAD signaling. Nature biotechnology, 27(3), 275-280. https:// doi.org/10.1038/nbt.1529

26. Gerrard, L., Rodgers, L., \& Cui, W. (2005). Differentiation of human embryonic stem cells to neural lineages in adherent culture by blocking bone morphogenetic protein signaling. Stem cells (Dayton, Ohio), 23(9), 1234-1241. https://doi.org/10.1634/ stemcells.2005-0110

27. Pruszak, J., Sonntag, K.-C., Aung, M. H., Sanchez-Pernaute, R., \& Isacson, O. (2007). Markers and methods for cell sorting of human embryonic stem cell-derived neural cell populations. Stem cells (Dayton, Ohio), 25(9), 2257-2268. https://doi.org/10.1634/ stemcells.2006-0744

28. Yuan, S. H., Martin, J., Elia, J., Flippin, J., Paramban, R. I., Hefferan, M. P., ... Carson, C. T. (2011). Cell-surface marker signatures for the isolation of neural stem cells, glia and neurons derived from human pluripotent stem cells. PloS one, 6(3), e17540. https://doi.org/10.1371/journal.pone.0017540

29. Kim, J., Efe, J. A., Zhu, S., Talantova, M., Yuan, X., Wang, S., ... Ding, S. (2011). Direct reprogramming of mouse fibroblasts to neural progenitors. Proceedings of the National Academy of Sciences of the United States of America, 108(19), 7838-7843. https://doi.org/10.1073/pnas.1103113108

30. Thier, M., Wörsdörfer, P., Lakes, Y. B., Gorris, R., Herms, S., Opitz, T., ... Edenhofer, F. (2012). Direct Conversion of Fibroblasts into Stably Expandable Neural Stem Cells. Cell Stem Cell, 10(4), 473-479. https://doi.org/10.1016/j.stem.2012.03.003.

31. Sheng, C., Zheng, Q., Wu, J., Xu, Z., Wang, L., Li, W., ... Zhou, Q. (2012). Direct reprogramming of Sertoli cells into multipotent neural stem cells by defined factors. Cell Research, 22(1), 208-218. https://doi.org/10.1038/cr.2011.175.

32. Lujan, E., Chanda, S., Ahlenius, H., Südhof, T. C., \& Wernig, M. (2012). Direct conversion of mouse fibroblasts to self-renewing, tripotent neural precursor cells. Proceedings of the National Academy of Sciences of the United States of America, 109(7), 2527-2532. https://doi.org/10.1073/pnas.1121003109

33. Ring, K. L., Tong, L. M., Balestra, M. E., Javier, R., AndrewsZwilling, Y., Li, G., ... Huang, Y. (2012). Direct Reprogramming of Mouse and Human Fibroblasts into Multipotent Neural Stem Cells with a Single Factor. Cell Stem Cell, 11(1), 100-109. https://doi.org/10.1016/j.stem.2012.05.018.

34. Giorgetti, A., Marchetto, M. C. N., Li, M., Yu, D., Fazzina, R., Mu, Y., ... Belmonte, J. C. I. (2012). Cord blood-derived neuronal cells by ectopic expression of Sox 2 and c-Myc. Proceedings of the National Academy of Sciences, 109(31), 1255612561. https://doi.org/10.1073/pnas.1209523109.

35. Zhang, T., Ke, W., Zhou, X., Qian, Y., Feng, S., Wang, R., ... Jing, N. (2019). Human Neural Stem Cells Reinforce 
Hippocampal Synaptic Network and Rescue Cognitive Deficits in a Mouse Model of Alzheimer's Disease. Stem Cell Reports, 13(6), 1022-1037. https://doi.org/10.1016/j.stemcr.2019.10.012.

36. Sheng, C., Jungverdorben, J., Wiethoff, H., Lin, Q., Flitsch, L. J., Eckert, D., ... Brüstle, O. (2018). A stably self-renewing adult blood-derived induced neural stem cell exhibiting patternability and epigenetic rejuvenation. Nature Communications, 9(1), 4047. https://doi.org/10.1038/s41467-018-06398-5.

37. Borghese, L., Dolezalova, D., Opitz, T., Haupt, S., Leinhaas, A., Steinfarz, B., ... Brüstle, O. (2010). Inhibition of notch signaling in human embryonic stem cell-derived neural stem cells delays G1/S phase transition and accelerates neuronal differentiation in vitro and in vivo. Stem cells (Dayton, Ohio), 28(5), 955-964. https://doi.org/10.1002/stem.408

38. Kirkeby, A., Grealish, S., Wolf, D. A., Nelander, J., Wood, J., Lundblad, M., ... Parmar, M. (2012). Generation of Regionally Specified Neural Progenitors and Functional Neurons from Human Embryonic Stem Cells under Defined Conditions. Cell Reports, 1(6), 703-714. https://doi.org/10.1016/j.celrep.2012.04. 009

39. Kriks, S., Shim, J.-W., Piao, J., Ganat, Y. M., Wakeman, D. R., Xie, Z., ... Studer, L. (2011). Dopamine neurons derived from human ES cells efficiently engraft in animal models of Parkinson's disease. Nature, 480(7378), 547-551. https://doi.org/10. 1038/nature10648

40. Strano, A., Tuck, E., Stubbs, V. E., \& Livesey, F. J. (2020). Variable outcomes in neural differentiation of human PSCs arise from intrinsic differences in developmental signaling pathways. Cell Reports, 31(10), 107732. https://doi.org/10.1016/j.celrep.2020. 107732

41. Tcw, J., Wang, M., Pimenova, A. A., Bowles, K. R., Hartley, B. J., Lacin, E., ... Brennand, K. J. (2017). An Efficient Platform for Astrocyte Differentiation from Human Induced Pluripotent Stem Cells. Stem Cell Reports, 9(2), 600-614. https://doi.org/10. 1016/j.stemcr.2017.06.018

42. Jana, M., Jana, A., Pal, U., \& Pahan, K. (2007). A Simplified Method for Isolating Highly Purified Neurons, Oligodendrocytes, Astrocytes, and Microglia from the Same Human Fetal Brain Tissue. Neurochemical Research, 32(12), 2015-2022. https://doi. org/10.1007/s11064-007-9340-y

43. Hu, W., Qiu, B., Guan, W., Wang, Q., Wang, M., Li, W., ... Pei, G. (2015). Direct Conversion of Normal and Alzheimer's Disease Human Fibroblasts into Neuronal Cells by Small Molecules. Cell Stem Cell, 17(2), 204-212. https://doi.org/10.1016/j.stem.2015. 07.006

44. Pang, Z. P., Yang, N., Vierbuchen, T., Ostermeier, A., Fuentes, D. R., Yang, T. Q., ... Wernig, M. (2011). Induction of human neuronal cells by defined transcription factors. Nature, 476(7359), 220-223. https://doi.org/10.1038/nature10202

45. Zhang, Y., Pak, C., Han, Y., Ahlenius, H., Zhang, Z., Chanda, S., ... Südhof, T. C. (2013). Rapid Single-Step Induction of Functional Neurons from Human Pluripotent Stem Cells. Neuron, 78(5), 785-798. https://doi.org/10.1016/j.neuron.2013.05. 029

46. Flitsch, L. J., Laupman, K. E., \& Brüstle, O. (2020). Transcription Factor-Based Fate Specification and Forward Programming for Neural Regeneration. Frontiers in Cellular Neuroscience, 14, 121. https://doi.org/10.3389/fncel.2020.00121

47. Yang, N., Chanda, S., Marro, S., Ng, Y.-H., Janas, J. A., Haag, D., ... Wernig, M. (2017). Generation of pure GABAergic neurons by transcription factor programming. Nature Methods, 14(6), 621-628. https://doi.org/10.1038/nmeth.4291

48. Nehme, R., Zuccaro, E., Ghosh, S. D., Li, C., Sherwood, J. L., Pietilainen, O., ... Eggan, K. (2018). Combining NGN2 Programming with Developmental Patterning Generates Human Excitatory Neurons with NMDAR-Mediated Synaptic
Transmission. Cell Reports, 23(8), 2509-2523. https://doi.org/ 10.1016/j.celrep.2018.04.066

49. Wang, C., Ward, M. E., Chen, R., Liu, K., Tracy, T. E., Chen, X., ... Gan, L. (2017). Scalable Production of iPSC-Derived Human Neurons to Identify Tau-Lowering Compounds by High-Content Screening. Stem Cell Reports, 9(4), 1221-1233. https://doi.org/ 10.1016/j.stemcr.2017.08.019

50. Binder, D. K., \& Scharfman, H. E. (2004). Mini Review. Growth Factors, 22(3), 123-131. https://doi.org/10.1080/0897719041 0001723308

51. Cintrón-Colón, A. F., Almeida-Alves, G., Boynton, A. M., \& Spitsbergen, J. M. (2020). GDNF synthesis, signaling, and retrograde transport in motor neurons. Cell and Tissue Research, 382(1), 47-56. https://doi.org/10.1007/s00441-020-03287-6

52. Lepski, G. P., Jannes, C. E., Nikkhah, G., \& Bischofberger, J. (2013). cAMP promotes the differentiation of neural progenitor cells in vitro via modulation of voltage-gated calcium channels. Frontiers in Cellular Neuroscience, 7. https://doi.org/10.3389/ fncel.2013.00155

53. Jang, S., Cho, H.-H., Cho, Y.-B., Park, J.-S., \& Jeong, H.-S. (2010). Functional neural differentiation of human adipose tissue-derived stem cells using bFGF and forskolin. BMC Cell Biology, 11(1), 25. https://doi.org/10.1186/1471-2121-11-25

54. Janesick, A., Wu, S. C., \& Blumberg, B. (2015). Retinoic acid signaling and neuronal differentiation. Cellular and Molecular Life Sciences, 72(8), 1559-1576. https://doi.org/10.1007/ s00018-014-1815-9

55. Busskamp, V., Lewis, N. E., Guye, P., Ng, A. H., Shipman, S. L., Byrne, S. M., ... Church, G. M. (2014). Rapid neurogenesis through transcriptional activation in human stem cells. Molecular Systems Biology, 10(11), 760. https://doi.org/10.15252/msb. 20145508

56. Kim, Y., Park, J., \& Choi, Y. K. (2019). The Role of Astrocytes in the Central Nervous System Focused on BK Channel and Heme Oxygenase Metabolites: A Review. Antioxidants, 8(5). https:// doi.org/10.3390/antiox8050121

57. Li, K., Li, J., Zheng, J., \& Qin, S. (2019). Reactive Astrocytes in Neurodegenerative Diseases. Aging and Disease, 10(3), 664 675. https://doi.org/10.14336/AD.2018.0720

58. Byun, J. S., Lee, C. O., Oh, M., Cha, D., Kim, W.-K., Oh, K.-J., ... Han, B.-S. (2020). Rapid differentiation of astrocytes from human embryonic stem cells. Neuroscience Letters, 716, 134681. https://doi.org/10.1016/j.neulet.2019.134681

59. Janssen, K., Bahnassawy, L., Kiefer, C., Korffmann, J., Terstappen, G. C., Lakics, V., ... Reinhardt, P. (2019). Generating Human iPSC-Derived Astrocytes with Chemically Defined Medium for In vitro Disease Modeling. In C.-F. Mandenius \& J. A. Ross (Eds.), Cell-Based Assays Using iPSCs for Drug Development and Testing (Vol. 1994, pp. 31-39). New York, NY: Springer New York. https://doi.org/10.1007/ 978-1-4939-9477-9_3

60. Raman, S., Srinivasan, G., Brookhouser, N., Nguyen, T., Henson, T., Morgan, D., ... Brafman, D. A. (2020). A Defined and Scalable Peptide-Based Platform for the Generation of Human Pluripotent Stem Cell-Derived Astrocytes. ACS biomaterials science \& engineering, 6(6), 3477-3490. https://doi.org/10.1021/ acsbiomaterials.0c00067

61. Shaltouki, A., Peng, J., Liu, Q., Rao, M. S., \& Zeng, X. (2013). Efficient Generation of Astrocytes from Human Pluripotent Stem Cells in Defined Conditions. STEM CELLS, 31(5), 941-952. https://doi.org/10.1002/stem.1334

62. Haidet-Phillips, A. M., Hester, M. E., Miranda, C. J., Meyer, K., Braun, L., Frakes, A., ... Kaspar, B. K. (2011). Astrocytes from Familial and Sporadic ALS Patients are Toxic to Motor Neurons. Nature biotechnology, 29(9), 824-828. https://doi.org/10.1038/ nbt. 1957 
63. Krencik, R., Weick, J. P., Liu, Y., Zhang, Z.-J., \& Zhang, S.-C. (2011). Specification of transplantable astroglial subtypes from human pluripotent stem cells. Nature Biotechnology, 29(6), 528-534. https://doi.org/10.1038/nbt.1877

64. McGivern, J. V., Patitucci, T. N., Nord, J. A., Barabas, M.-E.A., Stucky, C. L., \& Ebert, A. D. (2013). Spinal muscular atrophy astrocytes exhibit abnormal calcium regulation and reduced growth factor production: Dysfunctional SMA Astrocytes. Glia, 61(9), 1418-1428. https://doi.org/10.1002/glia.22522

65. Serio, A., Bilican, B., Barmada, S. J., Ando, D. M., Zhao, C., Siller, R., ... Chandran, S. (2013). Astrocyte pathology and the absence of non-cell autonomy in an induced pluripotent stem cell model of TDP-43 proteinopathy. Proceedings of the National Academy of Sciences of the United States of America, 110(12), 4697-4702. https://doi.org/10.1073/pnas. 1300398110

66. Jiang, P., Chen, C., Wang, R., Chechneva, O. V., Chung, S.-H., Rao, M. S., ... Deng, W. (2013). hESC-derived Olig2 + progenitors generate a subtype of astroglia with protective effects against ischaemic brain injury. Nature Communications, 4(1), 2196. https://doi.org/10.1038/ncomms3196

67. Chen, H., Qian, K., Chen, W., Hu, B., Blackbourn, L. W., Du, Z., ... Zhang, S.-C. (2015). Human-derived neural progenitors functionally replace astrocytes in adult mice. Journal of Clinical Investigation, 125(3), 1033-1042. https://doi.org/10.1172/JCI69 097

68. Chaboub, L. S., \& Deneen, B. (2013). Astrocyte form and function in the developing central nervous system. Seminars in Pediatric Neurology, 20(4), 230-235. https://doi.org/10.1016/j.spen. 2013.10.003

69. Canals, I., Ginisty, A., Quist, E., Timmerman, R., Fritze, J., Miskinyte, G., ... Ahlenius, H. (2018). Rapid and efficient induction of functional astrocytes from human pluripotent stem cells. Nature Methods, 15(9), 693-696. https://doi.org/10.1038/ s41592-018-0103-2

70. Li, X., Tao, Y., Bradley, R., Du, Z., Tao, Y., Kong, L., ... Zhang, S.-C. (2018). Fast Generation of Functional Subtype Astrocytes from Human Pluripotent Stem Cells. Stem Cell Reports, 11(4), 998-1008. https://doi.org/10.1016/j.stemcr.2018.08.019

71. Tchieu, J., Calder, E. L., Guttikonda, S. R., Gutzwiller, E. M., Aromolaran, K. A., Steinbeck, J. A., ... Studer, L. (2019). NFIA is a gliogenic switch enabling rapid derivation of functional human astrocytes from pluripotent stem cells. Nature Biotechnology, 37(3), 267-275. https://doi.org/10.1038/s41587-019-0035-0

72. Santos, R., Vadodaria, K. C., Jaeger, B. N., Mei, A., LefcochilosFogelquist, S., Mendes, A. P. D., ... Gage, F. H. (2017). Differentiation of Inflammation-Responsive Astrocytes from Glial Progenitors Generated from Human Induced Pluripotent Stem Cells. Stem Cell Reports, 8(6), 1757-1769. https://doi.org/10. 1016/j.stemcr.2017.05.011

73. Oksanen, M., Petersen, A. J., Naumenko, N., Puttonen, K., Lehtonen, Š., Gubert Olivé, M., ... Koistinaho, J. (2017). PSEN1 Mutant iPSC-Derived Model Reveals Severe Astrocyte Pathology in Alzheimer's Disease. Stem Cell Reports, 9(6), 1885-1897. https://doi.org/10.1016/j.stemcr.2017.10.016

74. Zhao, J., Davis, M. D., Martens, Y. A., Shinohara, M., GraffRadford, N. R., Younkin, S. G., ... Bu, G. (2017). APOE $\varepsilon 4 / \varepsilon 4$ diminishes neurotrophic function of human iPSC-derived astrocytes. Human Molecular Genetics, 26(14), 2690-2700. https:// doi.org/10.1093/hmg/ddx155

75. Zhou, B., Zuo, Y.-X., \& Jiang, R.-T. (2019). Astrocyte morphology: Diversity, plasticity, and role in neurological diseases. CNS Neuroscience \& Therapeutics, 25(6), 665-673. https://doi.org/ $10.1111 / \mathrm{cns} .13123$

76. Ren, B., \& Dunaevsky, A. (2021). Modeling Neurodevelopmental and Neuropsychiatric Diseases with Astrocytes Derived from Human-Induced Pluripotent Stem Cells. International Journal of Molecular Sciences, 22(4), 1692. https://doi.org/10.3390/ijms2 2041692

77. Bonaguidi, M. A., McGuire, T., Hu, M., Kan, L., Samanta, J., \& Kessler, J. A. (2005). LIF and BMP signaling generate separate and discrete types of GFAP-expressing cells. Development, 132(24), 5503-5514. https://doi.org/10.1242/dev.02166

78. Koblar, S. A., Turnley, A. M., Classon, B. J., Reid, K. L., Ware, C. B., Cheema, S. S., ... Bartlett, P. F. (1998). Neural precursor differentiation into astrocytes requires signaling through the leukemia inhibitory factor receptor. Proceedings of the National Academy of Sciences, 95(6), 3178-3181. https://doi.org/10.1073/ pnas.95.6.3178

79. Sakry, D., Neitz, A., Singh, J., Frischknecht, R., Marongiu, D., Binamé, F., ... Mittmann, T. (2014). Oligodendrocyte Precursor Cells Modulate the Neuronal Network by Activity-Dependent Ectodomain Cleavage of Glial NG2. PLoS Biology, 12(11), e1001993. https://doi.org/10.1371/journal.pbio.1001993

80. Kuhn, S., Gritti, L., Crooks, D., \& Dombrowski, Y. (2019). Oligodendrocytes in Development, Myelin Generation and Beyond. Cells, 8(11), 1424. https://doi.org/10.3390/cells8111424

81. Nistor, G. I., Totoiu, M. O., Haque, N., Carpenter, M. K., \& Keirstead, H. S. (2005). Human embryonic stem cells differentiate into oligodendrocytes in high purity and myelinate after spinal cord transplantation. Glia, 49(3), 385-396. https://doi.org/10. 1002/glia.20127

82. Izrael, M., Zhang, P., Kaufman, R., Shinder, V., Ella, R., Amit, M., ... Revel, M. (2007). Human oligodendrocytes derived from embryonic stem cells: Effect of noggin on phenotypic differentiation in vitro and on myelination in vivo. Molecular and Cellular Neuroscience, 34(3), 310-323. https://doi.org/10.1016/j.mcn. 2006.11.008

83. Hsieh, J., Aimone, J. B., Kaspar, B. K., Kuwabara, T., Nakashima, K., \& Gage, F. H. (2004). IGF-I instructs multipotent adult neural progenitor cells to become oligodendrocytes. The Journal of Cell Biology, 164(1), 111-122. https://doi.org/ 10.1083/jcb.200308101

84. Gil, J.-E., Woo, D.-H., Shim, J.-H., Kim, S.-E., You, H.-J., Park, S.-H., ... Kim, J.-H. (2009). Vitronectin promotes oligodendrocyte differentiation during neurogenesis of human embryonic stem cells. FEBS Letters, 583(3), 561-567. https://doi.org/10. 1016/j.febslet.2008.12.061

85. Kang, S.-M., Cho, M. S., Seo, H., Yoon, C. J., Oh, S. K., Choi, Y. M., \& Kim, D.-W. (2007). Efficient induction of oligodendrocytes from human embryonic stem cells. Stem Cells, 25(2), 419-424. https://doi.org/10.1634/stemcells.2005-0482

86. Piao, J., Major, T., Auyeung, G., Policarpio, E., Menon, J., Droms, L., ... Tabar, V. (2015). Human embryonic stem cellderived oligodendrocyte progenitors remyelinate the brain and rescue behavioral deficits following radiation. Cell Stem Cell, 16(2), 198-210. https://doi.org/10.1016/j.stem.2015.01.004

87. Sundberg, M., Skottman, H., Suuronen, R., \& Narkilahti, S. (2010). Production and isolation of NG2+ oligodendrocyte precursors from human embryonic stem cells in defined serum-free medium. Stem Cell Research, 5(2), 91-103. https://doi.org/10. 1016/j.scr.2010.04.005

88. Wang, S., Bates, J., Li, X., Schanz, S., Chandler-Militello, D., Levine, C., ... Goldman, S. A. (2013). Human iPSC-derived oligodendrocyte progenitor cells can myelinate and rescue a mouse model of congenital hypomyelination. Cell Stem Cell, 12(2), 252-264. https://doi.org/10.1016/j.stem.2012.12.002

89. Li, P., Li, M., Tang, X., Wang, S., Zhang, Y. A., \& Chen, Z. (2016). Accelerated generation of oligodendrocyte progenitor cells from human induced pluripotent stem cells by forced expression of Sox 10 and Olig2. Science China Life Sciences, 59(11), 1131-1138. https://doi.org/10.1007/ s11427-016-0165-3 
90. Maire, C. L., Buchet, D., Kerninon, C., Deboux, C., Baron-Van Evercooren, A., \& Nait-Oumesmar, B. (2009). Directing human neural stem/precursor cells into oligodendrocytes by overexpression of Olig2 transcription factor. Journal of Neuroscience Research, 87(15), 3438-3446. https://doi.org/10.1002/jnr.22194

91. Pawlowski, M., Ortmann, D., Bertero, A., Tavares, J. M., Pedersen, R. A., Vallier, L., \& Kotter, M. R. N. (2017). Inducible and deterministic forward programming of human Pluripotent stem cells into neurons, skeletal myocytes, and oligodendrocytes. Stem Cell Reports, 8(4), 803-812. https://doi.org/10.1016/j.stemcr. 2017.02.016

92. Wang, J., Pol, S. U., Haberman, A. K., Wang, C., O’Bara, M. A., \& Sim, F. J. (2014). Transcription factor induction of human oligodendrocyte progenitor fate and differentiation. Proceedings of the National Academy of Sciences, 111(28), E2885-E2894. https://doi.org/10.1073/pnas.1408295111

93. García-León, J. A., Kumar, M., Boon, R., Chau, D., One, J., Wolfs, E., ... Verfaillie, C. M. (2018). SOX10 Single Transcription Factor-Based Fast and Efficient Generation of Oligodendrocytes from Human Pluripotent Stem Cells. Stem Cell Reports, 10(2), 655-672. https://doi.org/10.1016/j.stemcr.2017.12.014

94. Madhavan, M., Nevin, Z. S., Shick, H. E., Garrison, E., Clarkson-Paredes, C., Karl, M., ... Tesar, P. J. (2018). Induction of myelinating oligodendrocytes in human cortical spheroids. Nature Methods, 15(9), 700-706. https://doi.org/10.1038/ s41592-018-0081-4

95. McKinnon, R. D., Matsui, T., Dubois-Dalcq, M., \& Aaronsont, S. A. (1990). FGF modulates the PDGF-driven pathway of oligodendrocyte development. Neuron, 5(5), 603-614. https://doi. org/10.1016/0896-6273(90)90215-2

96. Baron, W., Shattil, S. J., \& ffrench-Constant, C. (2002). The oligodendrocyte precursor mitogen PDGF stimulates proliferation by activation of $\alpha \mathrm{v} \beta 3$ integrins. The EMBO Journal, 21(8), 1957-1966. https://doi.org/10.1093/emboj/21.8.1957

97. Baron, W., Metz, B., Bansal, R., Hoekstra, D., \& de Vries, H. (2000). PDGF and FGF-2 Signaling in oligodendrocyte progenitor cells: regulation of proliferation and differentiation by multiple intracellular signaling pathways. Molecular and Cellular Neuroscience, 15(3), 314-329. https://doi.org/10.1006/mcne. 1999.0827

98. Yang, J., Cheng, X., Qi, J., Xie, B., Zhao, X., Zheng, K., ... Qiu, M. (2017). EGF Enhances Oligodendrogenesis from Glial Progenitor Cells. Frontiers in Molecular Neuroscience, 10. https:// doi.org/10.3389/fnmol.2017.00106

99. Laouarem, Y., \& Traiffort, E. (2018). Developmental and Repairing Production of Myelin: The Role of Hedgehog Signaling. Frontiers in Cellular Neuroscience, 12. https://doi.org/10.3389/ fncel.2018.00305

100. Dai, Z.-M., Sun, S., Wang, C., Huang, H., Hu, X., Zhang, Z., ... Qiu, M. (2014). Stage-Specific Regulation of Oligodendrocyte Development by Wnt/ $\beta$-Catenin Signaling. Journal of Neuroscience, 34(25), 8467-8473. https://doi.org/10.1523/JNEUROSCI. 0311-14.2014

101. Shi, B., Ding, J., Liu, Y., Zhuang, X., Zhuang, X., Chen, X., \& Fu, C. (2014). ERK1/2 pathway-mediated differentiation of IGF1-transfected spinal cord-derived neural stem Cells into oligodendrocytes. PLoS ONE, 9(8), e106038. https://doi.org/10.1371/ journal.pone.0106038

102. Dugas, J. C., Ibrahim, A., \& Barres, B. A. (2012). The T3-induced gene KLF9 regulates oligodendrocyte differentiation and myelin regeneration. Molecular and Cellular Neuroscience, 50(1), 45-57. https://doi.org/10.1016/j.mcn.2012.03.007

103. Hubler, Z., Allimuthu, D., Bederman, I., Elitt, M. S., Madhavan, M., Allan, K. C., ... Adams, D. J. (2018). Accumulation of 8,9-unsaturated sterols drives oligodendrocyte formation and remyelination. Nature, 560(7718), 372-376. https://doi.org/10. 1038/s41586-018-0360-3

104. Ehrlich, M., Mozafari, S., Glatza, M., Starost, L., Velychko, S., Hallmann, A.-L., ... Kuhlmann, T. (2017). Rapid and efficient generation of oligodendrocytes from human induced pluripotent stem cells using transcription factors. Proceedings of the National Academy of Sciences, 114(11), E2243-E2252. https:// doi.org/10.1073/pnas.1614412114

105. Liu, Z., Hu, X., Cai, J., Liu, B., Peng, X., Wegner, M., \& Qiu, M. (2007). Induction of oligodendrocyte differentiation by Olig2 and Sox 10: Evidence for reciprocal interactions and dosage-dependent mechanisms. Developmental Biology, 302(2), 683-693. https://doi.org/10.1016/j.ydbio.2006.10.007

106. Finzsch, M., Stolt, C. C., Lommes, P., \& Wegner, M. (2008). Sox 9 and Sox 10 influence survival and migration of oligodendrocyte precursors in the spinal cord by regulating PDGF receptor $\alpha$ expression. Development, 135(4), 637-646. https://doi.org/10. 1242/dev.010454

107. Pozniak, C. D., Langseth, A. J., Dijkgraaf, G. J. P., Choe, Y., Werb, Z., \& Pleasure, S. J. (2010). Sox 10 directs neural stem cells toward the oligodendrocyte lineage by decreasing Suppressor of Fused expression. Proceedings of the National Academy of Sciences, 107(50), 21795-21800. https://doi.org/10.1073/pnas. 1016485107

108. Stolt, C. C., Rehberg, S., Ader, M., Lommes, P., Riethmacher, D., Schachner, M., ... Wegner, M. (2002). Terminal differentiation of myelin-forming oligodendrocytes depends on the transcription factor Sox10. Genes \& Development, 16(2), 165-170. https://doi. org/10.1101/gad.215802

109. Nayak, D., Roth, T. L., \& McGavern, D. B. (2014). Microglia Development and Function. Annual Review of Immunology, 32(1), 367-402. https://doi.org/10.1146/annurev-immun ol-032713-120240

110. Kierdorf, K., \& Prinz, M. (2017). Microglia in steady state. Journal of Clinical Investigation, 127(9), 3201-3209. https://doi.org/ 10.1172/JCI90602

111. Muffat, J., Li, Y., Yuan, B., Mitalipova, M., Omer, A., Corcoran, S., ... Jaenisch, R. (2016). Efficient derivation of microglialike cells from human pluripotent stem cells. Nature Medicine, 22(11), 1358-1367. https://doi.org/10.1038/nm.4189

112. Speicher, A. M., Wiendl, H., Meuth, S. G., \& Pawlowski, M. (2019). Generating microglia from human pluripotent stem cells: Novel in vitro models for the study of neurodegeneration. Molecular Neurodegeneration, 14(1), 46. https://doi.org/10. 1186/s13024-019-0347-z

113. Haenseler, W., Sansom, S. N., Buchrieser, J., Newey, S. E., Moore, C. S., Nicholls, F. J., ... Cowley, S. A. (2017). A highly efficient human pluripotent stem cell microglia model displays a neuronal-co-culture-specific expression profile and inflammatory response. Stem Cell Reports, 8(6), 1727-1742. https:// doi.org/10.1016/j.stemcr.2017.05.017

114. Abud, E. M., Ramirez, R. N., Martinez, E. S., Healy, L. M., Nguyen, C. H. H., Newman, S. A., ... Blurton-Jones, M. (2017). iPSC-Derived Human Microglia-like Cells to Study Neurological Diseases. Neuron, 94(2), 278-293.e9. https://doi. org/10.1016/j.neuron.2017.03.042

115. Douvaras, P., Sun, B., Wang, M., Kruglikov, I., Lallos, G., Zimmer, M., ... Fossati, V. (2017). Directed Differentiation of Human Pluripotent Stem Cells to Microglia. Stem Cell Reports, 8(6), 1516-1524. https://doi.org/10.1016/j.stemcr.2017.04.023

116. Pandya, H., Shen, M. J., Ichikawa, D. M., Sedlock, A. B., Choi, Y., Johnson, K. R., .. Park, J. K. (2017). Differentiation of human and murine induced pluripotent stem cells to microglialike cells. Nature Neuroscience, 20(5), 753-759. https://doi. org/10.1038/nn.4534 
117. Takata, K., Kozaki, T., Lee, C. Z. W., Thion, M. S., Otsuka, M., Lim, S., ... Ginhoux, F. (2017). Induced-pluripotent-stem-cellderived primitive macrophages provide a platform for modeling tissue-resident macrophage differentiation and function. Immunity, 47(1), 183-198.e6. https://doi.org/10.1016/j.immuni. 2017.06.017

118. Kierdorf, K., Erny, D., Goldmann, T., Sander, V., Schulz, C., Perdiguero, E. G., ... Prinz, M. (2013). Microglia emerge from erythromyeloid precursors via Pu.1- and Irf8-dependent pathways. Nature Neuroscience, 16(3), 273-280. https://doi.org/ $10.1038 / \mathrm{nn} .3318$

119. Smith, L. T., Hohaus, S., Gonzalez, D. A., Dziennis, S. E., \& Tenen, D. G. (1996). PU.1 (Spi-1) and C/EBP alpha regulate the granulocyte colony-stimulating factor receptor promoter in myeloid cells. Blood, 88(4), 1234-1247.

120. Zhang, D. E., Hetherington, C. J., Chen, H. M., \& Tenen, D. G. (1994). The macrophage transcription factor PU.1 directs tissue-specific expression of the macrophage colony-stimulating factor receptor. Molecular and Cellular Biology, 14(1), 373-381. https://doi.org/10.1128/mcb.14.1.373

121. Kurotaki, D., Yamamoto, M., Nishiyama, A., Uno, K., Ban, T., Ichino, M., ... Tamura, T. (2014). IRF8 inhibits C/EBP $\alpha$ activity to restrain mononuclear phagocyte progenitors from differentiating into neutrophils. Nature Communications, 5(1), 4978. https://doi.org/10.1038/ncomms5978

122. Satoh, J., Asahina, N., Kitano, S., \& Kino, Y. (2014). A Comprehensive Profile of ChIP-Seq-Based PU.1/Spi1 Target Genes in Microglia. Gene Regulation and Systems Biology, 8, GRSB. S19711. https://doi.org/10.4137/GRSB.S19711

123. Wei, S., Nandi, S., Chitu, V., Yeung, Y.-G., Yu, W., Huang, M., ... Stanley, E. R. (2010). Functional overlap but differential expression of CSF-1 and IL-34 in their CSF-1 receptormediated regulation of myeloid cells. Journal of Leukocyte Biology, 88(3), 495-505. https://doi.org/10.1189/jlb.1209822

124. Terashima, T., Nakae, Y., Katagi, M., Okano, J., Suzuki, Y., \& Kojima, H. (2018). Stem cell factor induces polarization of microglia to the neuroprotective phenotype in vitro. Heliyon, 4(10). https://doi.org/10.1016/j.heliyon.2018.e00837

125. Zhang, S. C., \& Fedoroff, S. (1998). Modulation of microglia by stem cell factor. Journal of Neuroscience Research, 53(1), 29-37. https://doi.org/10.1002/(SICI)1097-4547(19980701) 53:1\%3c29::AID-JNR4\%3e3.0.CO;2-L

126. Horvath, S. (2013). DNA methylation age of human tissues and cell types. Genome Biology, 14(10), R115. https://doi.org/10. 1186/gb-2013-14-10-r115

127. Suhr, S. T., Chang, E. A., Rodriguez, R. M., Wang, K., Ross, P. J., Beyhan, Z., ... Cibelli, J. B. (2009). Telomere Dynamics in Human Cells Reprogrammed to Pluripotency. PLoS ONE, 4(12), e8124. https://doi.org/10.1371/journal.pone.0008124

128. Suhr, S. T., Chang, E. A., Tjong, J., Alcasid, N., Perkins, G. A., Goissis, M. D., ... Cibelli, J. B. (2010). Mitochondrial Rejuvenation After Induced Pluripotency. PLoS ONE, 5(11), e14095. https://doi.org/10.1371/journal.pone.0014095

129. Mertens, J., Marchetto, M. C., Bardy, C., \& Gage, F. H. (2016). Evaluating cell reprogramming, differentiation and conversion technologies in neuroscience. Nature Reviews Neuroscience, 17(7), 424-437. https://doi.org/10.1038/nrn.2016.46

130. Mertens, J., Reid, D., Lau, S., Kim, Y., \& Gage, F. H. (2018). Aging in a Dish: IPSC-Derived and Directly Induced Neurons for Studying Brain Aging and Age-Related Neurodegenerative Diseases. Annual Review of Genetics, 52, 271-293. https://doi. org/10.1146/annurev-genet-120417-031534

131. Traxler, L., Edenhofer, F., \& Mertens, J. (2019). Next-generation disease modeling with direct conversion: A new path to old neurons. FEBS Letters, 593(23), 3316-3337. https://doi.org/10.1002/ 1873-3468.13678
132. Miller, J. D., Ganat, Y. M., Kishinevsky, S., Bowman, R. L., Liu, B., Tu, E. Y., ... Studer, L. (2013). Human iPSC-Based Modeling of Late-Onset Disease via Progerin-Induced Aging. Cell Stem Cell, 13(6), 691-705. https://doi.org/10.1016/j.stem.2013.11.006

133. Vera, E., Bosco, N., \& Studer, L. (2016). Generating Late-Onset Human iPSC-Based Disease Models by Inducing Neuronal AgeRelated Phenotypes through Telomerase Manipulation. Cell Reports, 17(4), 1184-1192. https://doi.org/10.1016/j.celrep. 2016.09.062

134. Nekrasov, E. D., Vigont, V. A., Klyushnikov, S. A., Lebedeva, O. S., Vassina, E. M., Bogomazova, A. N., ... Kiselev, S. L. (2016). Manifestation of Huntington's disease pathology in human induced pluripotent stem cell-derived neurons. Molecular Neurodegeneration, 11(1), 27. https://doi.org/10.1186/ s13024-016-0092-5

135. Petersen, G. F., \& Strappe, P. M. (2016). Generation of diverse neural cell types through direct conversion. World Journal of Stem Cells, 8(2), 32-46. https://doi.org/10.4252/wjsc.v8.i2.32

136. Marro, S., Pang, Z. P., Yang, N., Tsai, M.-C., Qu, K., Chang, H. Y., ... Wernig, M. (2011). Direct Lineage Conversion of Terminally Differentiated Hepatocytes to Functional Neurons. Cell Stem Cell, 9(4), 374-382. https://doi.org/10.1016/j.stem.2011. 09.002

137. Ambasudhan, R., Talantova, M., Coleman, R., Yuan, X., Zhu, S., Lipton, S. A., \& Ding, S. (2011). Direct reprogramming of adult human fibroblasts to functional neurons under defined conditions. Cell Stem Cell, 9(2), 113-118. https://doi.org/10.1016/j. stem.2011.07.002

138. Huh, C. J., Zhang, B., Victor, M. B., Dahiya, S., Batista, L. F., Horvath, S., \& Yoo, A. S. (2016). Maintenance of age in human neurons generated by microRNA-based neuronal conversion of fibroblasts. eLife, 5, e18648. https://doi.org/10.7554/eLife.18648

139. Yoo, A. S., Sun, A. X., Li, L., Shcheglovitov, A., Portmann, T., Li, Y., ... Crabtree, G. R. (2011). MicroRNA-mediated conversion of human fibroblasts to neurons. Nature, 476(7359), 228 231. https://doi.org/10.1038/nature10323

140. Mertens, J., Paquola, A. C. M., Ku, M., Hatch, E., Böhnke, L., Ladjevardi, S., ... Gage, F. H. (2015). Directly Reprogrammed Human Neurons Retain Aging-Associated Transcriptomic Signatures and Reveal Age-Related Nucleocytoplasmic Defects. Cell Stem Cell, 17(6), 705-718. https://doi.org/10.1016/j.stem.2015. 09.001

141. Luo, C., Lee, Q. Y., Wapinski, O., Castanon, R., Nery, J. R., Mall, M., ... Ecker, J. R. (2019). Global DNA methylation remodeling during direct reprogramming of fibroblasts to neurons. eLife, 8 , e40197. https://doi.org/10.7554/eLife.40197

142. Lancaster, M. A., Renner, M., Martin, C.-A., Wenzel, D., Bicknell, L. S., Hurles, M. E., ... Knoblich, J. A. (2013). Cerebral organoids model human brain development and microcephaly. Nature, 501(7467). https://doi.org/10.1038/nature12517

143. Koo, B., Choi, B., Park, H., \& Yoon, K.-J. (2019). Past, Present, and Future of Brain Organoid Technology. Molecules and Cells, 42(9), 617-627. https://doi.org/10.14348/molcells.2019.0162

144. Qian, X., Song, H., \& Ming, G.-L. (2019). Brain organoids: advances, applications and challenges. Development (Cambridge, England), 146(8). https://doi.org/10.1242/dev.166074

145. Paşca, A. M., Sloan, S. A., Clarke, L. E., Tian, Y., Makinson, C. D., Huber, N., ... Paşca, S. P. (2015). Functional cortical neurons and astrocytes from human pluripotent stem cells in 3D culture. Nature Methods, 12(7), 671-678. https://doi.org/10.1038/nmeth. 3415

146. Muguruma, K., Nishiyama, A., Kawakami, H., Hashimoto, K., \& Sasai, Y. (2015). Self-organization of polarized cerebellar tissue in 3D culture of human pluripotent stem cells. Cell Reports, 10(4), 537-550. https://doi.org/10.1016/j.celrep.2014.12.051 
147. Sakaguchi, H., Kadoshima, T., Soen, M., Narii, N., Ishida, Y., Ohgushi, M., ... Sasai, Y. (2015). Generation of functional hippocampal neurons from self-organizing human embryonic stem cell-derived dorsomedial telencephalic tissue. Nature Coтmиnications, 6, 8896. https://doi.org/10.1038/ncomms9896

148. Jo, J., Xiao, Y., Sun, A. X., Cukuroglu, E., Tran, H.-D., Göke, J., ... Ng, H.-H. (2016). Midbrain-like Organoids from Human Pluripotent Stem Cells Contain Functional Dopaminergic and Neuromelanin-Producing Neurons. Cell Stem Cell, 19(2), 248257. https://doi.org/10.1016/j.stem.2016.07.005

149. Rossetti, A. C., Koch, P., \& Ladewig, J. (2019). Drug discovery in psychopharmacology: From 2D models to cerebral organoids. Dialogues in Clinical Neuroscience, 21(2), 203-224.

150. Linkous, A., Balamatsias, D., Snuderl, M., Edwards, L., Miyaguchi, K., Milner, T., ... Fine, H. A. (2019). Modeling Patient-Derived Glioblastoma with Cerebral Organoids. Cell Reports, 26(12), 32033211.e5. https://doi.org/10.1016/j.celrep.2019.02.063

151. Yagi, T., Ito, D., Okada, Y., Akamatsu, W., Nihei, Y., Yoshizaki, T., ... Suzuki, N. (2011). Modeling familial Alzheimer's disease with induced pluripotent stem cells. Human Molecular Genetics, 20(23), 4530-4539. https://doi.org/10.1093/hmg/ddr394

152. Hossini, A. M., Megges, M., Prigione, A., Lichtner, B., Toliat, M. R., Wruck, W., ... Adjaye, J. (2015). Induced pluripotent stem cell-derived neuronal cells from a sporadic Alzheimer's disease donor as a model for investigating AD-associated gene regulatory networks. BMC Genomics, 16(1), 84. https://doi.org/ 10.1186/s12864-015-1262-5

153. Young, J. E., Boulanger-Weill, J., Williams, D. A., Woodruff, G., Buen, F., Revilla, A. C., ... Goldstein, L. S. B. (2015). Elucidating molecular phenotypes caused by the SORL1 Alzheimer's disease genetic risk factor using human induced pluripotent stem cells. Cell Stem Cell, 16(4), 373-385. https://doi.org/10.1016/j. stem.2015.02.004

154. Knupp, A., Mishra, S., Martinez, R., Braggin, J. E., Szabo, M., Kinoshita, C., ... Young, J. E. (2020). Depletion of the AD Risk Gene SORL1 Selectively Impairs Neuronal Endosomal Traffic Independent of Amyloidogenic APP Processing. Cell reports, 31(9), 107719. https://doi.org/10.1016/j.celrep.2020.107719

155. Dawkins, E., \& Small, D. H. (2014). Insights into the physiological function of the $\beta$-amyloid precursor protein: Beyond Alzheimer's disease. Journal of Neurochemistry, 129(5), 756-769. https://doi.org/10.1111/jnc.12675

156. De Strooper, B., \& Karran, E. (2016). The Cellular Phase of Alzheimer's Disease. Cell, 164(4), 603-615. https://doi.org/10. 1016/j.cell.2015.12.056

157. Camara, H., \& De-Souza, E. A. (2018). $\beta$-Amyloid Accumulation Slows Earlier than Expected in Preclinical Alzheimer's Disease Patients. Journal of Neuroscience, 38(43), 9123-9125. https:// doi.org/10.1523/JNEUROSCI.1592-18.2018

158. Mah, N., Seltmann, S., Aran, B., Steeg, R., Dewender, J., Bultjer, N., ... Kurtz, A. (2020). Access to stem cell data and registration of pluripotent cell lines: The Human Pluripotent Stem Cell Registry (hPSCreg). Stem Cell Research, 47, 101887. https://doi. org/10.1016/j.scr.2020.101887

159. Raska, J., Klimova, H., Sheardova, K., Fedorova, V., Hribkova, H., Pospisilova, V., ... Bohaciakova, D. (2021). Generation of three human iPSC lines from patients with a spontaneous late-onset Alzheimer's disease and three sex- and age-matched healthy controls. Stem Cell Research, 53, 102378. https://doi.org/ 10.1016/j.scr.2021.102378

160. Raska, J., Hribkova, H., Klimova, H., Fedorova, V., Barak, M., Barta, T., ... Bohaciakova, D. (2021). Generation of six human iPSC lines from patients with a familial Alzheimer's disease $(\mathrm{n}=3)$ and sex- and age-matched healthy controls $(\mathrm{n}=3)$. Stem Cell Research, 53, 102379. https://doi.org/10.1016/j.scr.2021. 102379
161. D’Souza, G. X., Rose, S. E., Knupp, A., Nicholson, D. A., Keene, C. D., \& Young, J. E. (2020). The application of in vitro-derived human neurons in neurodegenerative disease modeling. Journal of Neuroscience Research. https://doi.org/10.1002/jnr.24615

162. de Leeuw, S., \& Tackenberg, C. (2019). Alzheimer's in a dish - induced pluripotent stem cell-based disease modeling. Translational Neurodegeneration, 8. https://doi.org/10.1186/ s40035-019-0161-0

163. Penney, J., Ralvenius, W. T., \& Tsai, L.-H. (2020). Modeling Alzheimer's disease with iPSC-derived brain cells. Molecular Psychiatry, 25(1), 148-167. https://doi.org/10.1038/ s41380-019-0468-3

164. Poon, A., Zhang, Y., Chandrasekaran, A., Phanthong, P., Schmid, B., Nielsen, T. T., \& Freude, K. K. (2017). Modeling neurodegenerative diseases with patient-derived induced pluripotent cells: Possibilities and challenges. New Biotechnology, 39, 190198. https://doi.org/10.1016/j.nbt.2017.05.009

165. Riemens, R. J. M., Kenis, G., \& van den Beucken, T. (2020). Human-induced pluripotent stem cells as a model for studying sporadic Alzheimer's disease. Neurobiology of Learning and Memory, 175, 107318. https://doi.org/10.1016/j.nlm.2020. 107318

166. Rowland, H. A., Hooper, N. M., \& Kellett, K. A. B. (2018). Modelling Sporadic Alzheimer's Disease Using Induced Pluripotent Stem Cells. Neurochemical Research, 43(12), 2179-2198. https://doi.org/10.1007/s11064-018-2663-z

167. Sullivan, S. E., \& Young-Pearse, T. L. (2017). Induced pluripotent stem cells as a discovery tool for Alzheimer's disease. Brain Research, 1656, 98-106. https://doi.org/10.1016/j.brainres.2015. 10.005

168. Tcw, J. (2019). Human iPSC application in Alzheimer's disease and Tau-related neurodegenerative diseases. Neuroscience Letters, 699, 31-40. https://doi.org/10.1016/j.neulet.2019.01.043

169. Jones, V. C., Atkinson-Dell, R., Verkhratsky, A., \& Mohamet, L. (2017). Aberrant iPSC-derived human astrocytes in Alzheimer's disease. Cell Death \& Disease, 8(3), e2696-e2696. https://doi. org/10.1038/cddis.2017.89

170. Koch, P., Tamboli, I. Y., Mertens, J., Wunderlich, P., Ladewig, J., Stüber, K., ... Walter, J. (2012). Presenilin-1 L166P mutant human pluripotent stem cell-derived neurons exhibit partial loss of $\gamma$-secretase activity in endogenous Amyloid- $\beta$ generation. The American Journal of Pathology, 180(6), 2404-2416. https://doi. org/10.1016/j.ajpath.2012.02.012

171. Meyer, K., Feldman, H. M., Lu, T., Drake, D., Lim, E. T., Ling, K.-H., ... Yankner, B. A. (2019). REST and Neural Gene Network Dysregulation in iPSC Models of Alzheimer's Disease. Cell Reports, 26(5), 1112-1127.e9. https://doi.org/10.1016/j.celrep. 2019.01.023

172. Paquet, D., Kwart, D., Chen, A., Sproul, A., Jacob, S., Teo, S., ... Tessier-Lavigne, M. (2016). Efficient introduction of specific homozygous and heterozygous mutations using CRISPR/ Cas9. Nature, 533(7601), 125-129. https://doi.org/10.1038/natur e17664

173. Sproul, A. A., Jacob, S., Pre, D., Kim, S. H., Nestor, M. W., Navarro-Sobrino, M., ... Noggle, S. A. (2014). Characterization and Molecular Profiling of PSEN1 Familial Alzheimer's Disease iPSC-Derived Neural Progenitors. PLOS ONE, 9(1), e84547. https://doi.org/10.1371/journal.pone.0084547

174. Yang, J., Zhao, H., Ma, Y., Shi, G., Song, J., Tang, Y., ... Le, W. (2017). Early pathogenic event of Alzheimer's disease documented in iPSCs from patients with PSEN1 mutations. Oncotarget, 8(5), 7900-7913. https://doi.org/10.18632/oncotarget. 13776

175. Pansri, P., Phanthong, P., Suthprasertporn, N., Kitiyanant, Y., Tubsuwan, A., Dinnyes, A., ... Kitiyanant, N. (2021). Brainderived neurotrophic factor increases cell number of neural 
progenitor cells derived from human induced pluripotent stem cells. PeerJ, 9, e11388. https://doi.org/10.7717/peerj.11388

176. Gunhanlar, N., Shpak, G., van der Kroeg, M., Gouty-Colomer, L. A., Munshi, S. T., Lendemeijer, B., ... Kushner, S. A. (2018). A simplified protocol for differentiation of electrophysiologically mature neuronal networks from human induced pluripotent stem cells. Molecular Psychiatry, 23(5), 1336-1344. https://doi.org/ 10.1038/mp.2017.56

177. Sun, A. X., Yuan, Q., Tan, S., Xiao, Y., Wang, D., Khoo, A. T. T., ... Je, H. S. (2016). Direct Induction and Functional Maturation of Forebrain GABAergic Neurons from Human Pluripotent Stem Cells. Cell Reports, 16(7), 1942-1953. https://doi.org/10.1016/j. celrep.2016.07.035

178. Duan, L., Bhattacharyya, B. J., Belmadani, A., Pan, L., Miller, R. J., \& Kessler, J. A. (2014). Stem cell derived basal forebrain cholinergic neurons from Alzheimer's disease patients are more susceptible to cell death. Molecular Neurodegeneration, 9(1), 3. https://doi.org/10.1186/1750-1326-9-3

179. Ortiz-Virumbrales, M., Moreno, C. L., Kruglikov, I., Marazuela, P., Sproul, A., Jacob, S., ... Gandy, S. (2017). CRISPR/Cas9Correctable mutation-related molecular and physiological phenotypes in iPSC-derived Alzheimer's PSEN2N141Ineurons. Acta Neuropathologica Communications, 5(1), 77. https://doi.org/10. 1186/s40478-017-0475-z

180. Mertens, J., Herdy, J. R., Traxler, L., Schafer, S. T., Schlachetzki, J. C. M., Böhnke, L., ... Gage, F. H. (2021). Age-dependent instability of mature neuronal fate in induced neurons from Alzheimer's patients. Cell Stem Cell. https://doi.org/10.1016/j.stem. 2021.04.004

181. Zhao, J., Fu, Y., Yamazaki, Y., Ren, Y., Davis, M. D., Liu, C.-C., ... Bu, G. (2020). APOE4 exacerbates synapse loss and neurodegeneration in Alzheimer's disease patient iPSC-derived cerebral organoids. Nature Communications, 11(1), 5540. https://doi.org/ 10.1038/s41467-020-19264-0

182. Hu, N.-W., Corbett, G. T., Moore, S., Klyubin, I., O’Malley, T. T., Walsh, D. M., ... Rowan, M. J. (2018). Extracellular Forms of $\mathrm{A} \beta$ and Tau from iPSC Models of Alzheimer's Disease Disrupt Synaptic Plasticity. Cell Reports, 23(7), 1932-1938. https://doi. org/10.1016/j.celrep.2018.04.040

183. Birnbaum, J. H., Wanner, D., Gietl, A. F., Saake, A., Kündig, T. M., Hock, C., ... Tackenberg, C. (2018). Oxidative stress and altered mitochondrial protein expression in the absence of amyloid- $\beta$ and tau pathology in iPSC-derived neurons from sporadic Alzheimer's disease patients. Stem Cell Research, 27, 121-130. https://doi.org/10.1016/j.scr.2018.01.019

184. Elsworthy, R. J., King, M. C., Grainger, A., Fisher, E., Crowe, J. A., Alqattan, S., ... Aldred, S. (2021). Amyloid- $\beta$ Precursor Protein Processing and Oxidative Stress are Altered in Human iPSC-Derived Neuron and Astrocyte Co-Cultures Carrying Presenillin-1 Gene Mutations Following Spontaneous Differentiation. Molecular and Cellular Neurosciences, 103631. https://doi. org/10.1016/j.mcn.2021.103631

185. Kwart, D., Gregg, A., Scheckel, C., Murphy, E. A., Paquet, D., Duffield, M., ... Tessier-Lavigne, M. (2019). A Large Panel of Isogenic APP and PSEN1 Mutant Human iPSC Neurons Reveals Shared Endosomal Abnormalities Mediated by APP $\beta$-CTFs, Not A . Neuron, 104(2), 256-270.e5. https://doi.org/10.1016/j.neuron.2019.07.010

186. Martín-Maestro, P., Gargini, R., A Sproul, A., García, E., Antón, L. C., Noggle, S., ... García-Escudero, V. (2017). Mitophagy Failure in Fibroblasts and iPSC-Derived Neurons of Alzheimer's Disease-Associated Presenilin 1 Mutation. Frontiers in Molecular Neuroscience, 10, 291. https://doi.org/10.3389/fnmol.2017. 00291

187. Li, L., Roh, J. H., Chang, E. H., Lee, Y., Lee, S., Kim, M., ... Song, J. (2018). iPSC Modeling of Presenilin1 Mutation in
Alzheimer's Disease with Cerebellar Ataxia. Experimental Neurobiology, 27(5), 350-364. https://doi.org/10.5607/en.2018.27.5. 350

188. Fang, E. F., Hou, Y., Palikaras, K., Adriaanse, B. A., Kerr, J. S., Yang, B., ... Bohr, V. A. (2019). Mitophagy inhibits amyloid- $\beta$ and tau pathology and reverses cognitive deficits in models of Alzheimer's disease. Nature Neuroscience, 22(3), 401-412. https://doi.org/10.1038/s41593-018-0332-9

189. van der Kant, R., Langness, V. F., Herrera, C. M., Williams, D. A., Fong, L. K., Leestemaker, Y., ... Goldstein, L. S. B. (2019). Cholesterol Metabolism Is a Druggable Axis that Independently Regulates Tau and Amyloid- $\beta$ in iPSC-Derived Alzheimer's Disease Neurons. Cell Stem Cell, 24(3), 363-375.e9. https://doi.org/ 10.1016/j.stem.2018.12.013

190. Muratore, C. R., Zhou, C., Liao, M., Fernandez, M. A., Taylor, W. M., Lagomarsino, V. N., ... Young-Pearse, T. L. (2017). Celltype Dependent Alzheimer's Disease Phenotypes: Probing the Biology of Selective Neuronal Vulnerability. Stem Cell Reports, 9(6), 1868-1884. https://doi.org/10.1016/j.stemcr.2017.10.015

191. Israel, M. A., Yuan, S. H., Bardy, C., Reyna, S. M., Mu, Y., Herrera, C., ... Goldstein, L. S. B. (2012). Probing sporadic and familial Alzheimer's disease using induced pluripotent stem cells. Nature, 482(7384), 216-220. https://doi.org/10.1038/nature10821

192. Moore, S., Evans, L. D. B., Andersson, T., Portelius, E., Smith, J., Dias, T. B., ... Livesey, F. J. (2015). APP Metabolism Regulates Tau Proteostasis in Human Cerebral Cortex Neurons. Cell Reports, 11(5), 689-696. https://doi.org/10.1016/j.celrep.2015.03.068

193. Muratore, C. R., Rice, H. C., Srikanth, P., Callahan, D. G., Shin, T., Benjamin, L. N. P., ... Young-Pearse, T. L. (2014). The familial Alzheimer's disease APPV717I mutation alters APP processing and Tau expression in iPSC-derived neurons. Human Molecular Genetics, 23(13), 3523-3536. https://doi.org/10.1093/hmg/ddu064

194. Woodruff, G., Reyna, S. M., Dunlap, M., Van Der Kant, R., Callender, J. A., Young, J. E., ... Goldstein, L. S. B. (2016). Defective Transcytosis of APP and Lipoproteins in Human iPSC-Derived Neurons with Familial Alzheimer's Disease Mutations. Cell Reports, 17(3), 759-773. https://doi.org/10.1016/j.celrep.2016.09.034

195. Chang, C.-Y., Chen, S.-M., Lu, H.-E., Lai, S.-M., Lai, P.-S., Shen, P.-W., ... Su, H.-L. (2015). N-butylidenephthalide attenuates Alzheimer's disease-like cytopathy in Down syndrome induced pluripotent stem cell-derived neurons. Scientific Reports, 5, 8744. https://doi.org/10.1038/srep08744

196. Konttinen, H., Gureviciene, I., Oksanen, M., Grubman, A., Loppi, S., Huuskonen, M. T., ... Malm, T. (2019). PPAR $\beta / \delta-$ agonist GW0742 ameliorates dysfunction in fatty acid oxidation in PSEN1 $\Delta$ E9 astrocytes. Glia, 67(1), 146-159. https://doi.org/ 10.1002/glia.23534

197. Mahairaki, V., Ryu, J., Peters, A., Chang, Q., Li, T., Park, T. S., ... Koliatsos, V. E. (2014). Induced pluripotent stem cells from familial Alzheimer's disease patients differentiate into mature neurons with amyloidogenic properties. Stem Cells and Development, 23(24), 2996-3010. https://doi.org/10.1089/scd.2013.0511

198. Kondo, T., Asai, M., Tsukita, K., Kutoku, Y., Ohsawa, Y., Sunada, Y., ... Inoue, H. (2013). Modeling Alzheimer's disease with iPSCs reveals stress phenotypes associated with intracellular $\mathrm{A} \beta$ and differential drug responsiveness. Cell Stem Cell, 12(4), 487-496. https://doi.org/10.1016/j.stem.2013.01.009

199. Oka, S., Leon, J., Sakumi, K., Ide, T., Kang, D., LaFerla, F. M., \& Nakabeppu, Y. (2016). Human mitochondrial transcriptional factor A breaks the mitochondria-mediated vicious cycle in Alzheimer's disease. Scientific Reports, 6(1), 37889. https://doi.org/ 10.1038/srep37889

200. Lu, J., Li, Y., Mollinari, C., Garaci, E., \& Pei*, D. M. and G. (2019, August 31). Amyloid- $\beta$ Oligomers-induced Mitochondrial DNA Repair Impairment Contributes to Altered Human Neural Stem Cell Differentiation. Current Alzheimer Research. 
Retrieved December 30, 2020, from https://www.eurekaselect. com/176056/article

201. Nieweg, K., Andreyeva, A., van Stegen, B., Tanriöver, G., \& Gottmann, K. (2015). Alzheimer's disease-related amyloid- $\beta$ induces synaptotoxicity in human iPS cell-derived neurons. Cell Death \& Disease, 6, e1709. https://doi.org/10.1038/cddis.2015.72

202. Vazin, T., Ball, K. A., Lu, H., Park, H., Ataeijannati, Y., HeadGordon, T., ... Schaffer, D. V. (2014). Efficient derivation of cortical glutamatergic neurons from human pluripotent stem cells: A model system to study neurotoxicity in Alzheimer's disease. Neurobiology of Disease, 62, 62-72. https://doi.org/10.1016/j. nbd.2013.09.005

203. Armijo, E., Gonzalez, C., Shahnawaz, M., Flores, A., Davis, B., \& Soto, C. (2017). Increased susceptibility to A $\beta$ toxicity in neuronal cultures derived from familial Alzheimer's disease (PSEN1-A246E) induced pluripotent stem cells. Neuroscience Letters, 639, 74-81. https://doi.org/10.1016/j.neulet.2016.12.060

204. Ochalek, A., Mihalik, B., Avci, H. X., Chandrasekaran, A., Téglási, A., Bock, I., ... Dinnyés, A. (2017). Neurons derived from sporadic Alzheimer's disease iPSCs reveal elevated TAU hyperphosphorylation, increased amyloid levels, and GSK3B activation. Alzheimer's Research \& Therapy, 9(1), 90. https://doi.org/ 10.1186/s13195-017-0317-z

205. Sienski, G., Narayan, P., Bonner, J. M., Kory, N., Boland, S., Arczewska, A. A., ... Lindquist, S. (2021). APOE4 disrupts intracellular lipid homeostasis in human iPSC-derived glia. Science Translational Medicine, 13(583). https://doi.org/10.1126/ scitranslmed.aaz4564

206. Langness, V. F., van der Kant, R., Das, U., Wang, L., dos Chaves, R., \& S., \& Goldstein, L. S. B. . (2020). Cholesterol-lowering drugs reduce APP processing to A $\beta$ by inducing APP dimerization. Molecular Biology of the Cell, 32(3), 247-259. https://doi. org/10.1091/mbc.E20-05-0345

207. Arber, C., Lovejoy, C., Harris, L., Willumsen, N., Alatza, A., Casey, J. M., ... Wray, S. (2021). Familial Alzheimer's Disease Mutations in PSEN1 Lead to Premature Human Stem Cell Neurogenesis. Cell Reports, 34(2), 108615. https://doi.org/10.1016/j.celrep.2020.108615

208. Vijayan, V. K., Geddes, J. W., Anderson, K. J., Chang-Chui, H., Ellis, W. G., \& Cotman, C. W. (1991). Astrocyte hypertrophy in the Alzheimer's disease hippocampal formation. Experimental Neurology, 112(1), 72-78. https://doi.org/10.1016/0014-4886(91)90115-s

209. Perez-Nievas, B. G., \& Serrano-Pozo, A. (2018). Deciphering the Astrocyte Reaction in Alzheimer's Disease. Frontiers in Aging Neuroscience, 10, 114. https://doi.org/10.3389/fnagi.2018.00114

210. Ben Haim, L., Carrillo-de Sauvage, M.-A., CeyzÃ@riat, K., \& Escartin, C. (2015). Elusive roles for reactive astrocytes in neurodegenerative diseases. Frontiers in Cellular Neuroscience, 9. https://doi.org/ 10.3389/fncel.2015.00278

211. Griffin, P., Sheehan, P. W., Dimitry, J. M., Guo, C., Kanan, M. F., Lee, J., ... Musiek, E. S. (2020). REV-ERB $\alpha$ mediates complement expression and diurnal regulation of microglial synaptic phagocytosis. eLife, 9, e58765. https://doi.org/10.7554/eLife.58765

212. Fong, L. K., Yang, M. M., Dos Santos Chaves, R., Reyna, S. M., Langness, V. F., Woodruff, G., ... Goldstein, L. S. B. (2018). Fulllength amyloid precursor protein regulates lipoprotein metabolism and amyloid- $\beta$ clearance in human astrocytes. The Journal of Biological Chemistry, 293(29), 11341-11357. https://doi.org/10.1074/ jbc.RA117.000441

213. Lin, Y.-T., Seo, J., Gao, F., Feldman, H. M., Wen, H.-L., Penney, J., ... Tsai, L.-H. (2018). APOE4 causes widespread molecular and cellular alterations associated with Alzheimer's disease phenotypes in human iPSC-derived brain cell types. Neuron, 98(6), 1141-1154. e7. https://doi.org/10.1016/j.neuron.2018.05.008

214. Tognatta, R., \& Miller, R. H. (2016). Contribution of the oligodendrocyte lineage to CNS repair and neurodegenerative pathologies.
Neuropharmacology, 110, 539-547. https://doi.org/10.1016/j.neuro pharm.2016.04.026

215. Nielsen, H. M., Ek, D., Avdic, U., Orbjörn, C., Hansson, O., Veerhuis, R., ... The Netherlands Brain Bank. (2013). NG2 cells, a new trail for Alzheimer's disease mechanisms? Acta Neuropathologica Communications, 1(1), 7. https://doi.org/10.1186/2051-5960-1-7

216. Roher, A. E., Weiss, N., Kokjohn, T. A., Kuo, Y.-M., Kalback, W., Anthony, J., ... Beach, T. (2002). Increased A $\beta$ peptides and reduced cholesterol and myelin proteins characterize white matter degeneration in alzheimer's disease. Biochemistry, 41(37), 11080-11090. https://doi.org/10.1021/bi026173d

217. Jantaratnotai, N., Ryu, J. K., Kim, S. U., \& McLarnon, J. G. (2003). Amyloid beta peptide-induced corpus callosum damage and glial activation in vivo. NeuroReport, 14(11), 1429-1433. https://doi.org/10.1097/00001756-200308060-00005

218. Czepiel, M., Balasubramaniyan, V., Schaafsma, W., Stancic, M., Mikkers, H., Huisman, C., ... Copray, S. (2011). Differentiation of induced pluripotent stem cells into functional oligodendrocytes. Glia, 59(6), 882-892. https://doi.org/10.1002/glia.21159

219. Livesey, M. R., Magnani, D., Cleary, E. M., Vasistha, N. A., James, O. T., Selvaraj, B. T., ... Chandran, S. (2016). Maturation and electrophysiological properties of human pluripotent stem cell-derived oligodendrocytes. STEM CELLS, 34(4), 1040-1053. https://doi.org/10.1002/stem.2273

220. Wolf, S. A., Boddeke, H. W. G. M., \& Kettenmann, H. (2017). Microglia in Physiology and Disease. Annual Review of Physiology, 79(1), 619-643. https://doi.org/10.1146/annurev-physi ol-022516-034406

221. Stelzmann, R. A., Schnitzlein, H. N., \& Murtagh, F. R. (1995). An english translation of alzheimer's 1907 paper, "über eine eigenartige erkankung der hirnrinde." Clinical Anatomy, 8(6), 429-431. https://doi.org/10.1002/ca.980080612

222. Graeber, M. B., Scheithauer, B. W., \& Kreutzberg, G. W. (2002). Microglia in brain tumors. Glia, 40(2), 252-259. https://doi.org/ 10.1002/glia.10147

223. Hickman, S. E., Allison, E. K., \& El Khoury, J. (2008). Microglial Dysfunction and Defective -Amyloid Clearance Pathways in Aging Alzheimer's Disease Mice. Journal of Neuroscience, 28(33), 8354-8360. https://doi.org/10.1523/JNEUROSCI.061608.2008

224. Liu, Z., Condello, C., Schain, A., Harb, R., \& Grutzendler, J. (2010). CX3CR1 in Microglia Regulates Brain Amyloid Deposition through Selective Protofibrillar Amyloid- $\beta$ Phagocytosis. Journal of Neuroscience, 30(50), 17091-17101. https://doi.org/ 10.1523/JNEUROSCI.4403-10.2010

225. Guillot-Sestier, M.-V., \& Town, T. (2013). Innate immunity in Alzheimer's disease: A complex affair. CNS \& neurological disorders drug targets, 12(5), 593-607. https://doi.org/10.2174/ 1871527311312050008

226. Jonsson, T., Stefansson, H., Steinberg, S., Jonsdottir, I., Jonsson, P. V., Snaedal, J., ... Stefansson, K. (2013). Variant of TREM2 Associated with the Risk of Alzheimer's Disease. New England Journal of Medicine, 368(2), 107-116. https://doi.org/10.1056/ NEJMoa1211103

227. Lambert, J. C., Ibrahim-Verbaas, C. A., Harold, D., Naj, A. C., Sims, R., Bellenguez, C., ... Amouyel, P. (2013). Meta-analysis of 74,046 individuals identifies 11 new susceptibility loci for Alzheimer's disease. Nature Genetics, 45(12), 1452-1458. https://doi.org/10.1038/ng.2802

228. Hansen, D. V., Hanson, J. E., \& Sheng, M. (2018). Microglia in Alzheimer's disease. Journal of Cell Biology, 217(2), 459-472. https://doi.org/10.1083/jcb.201709069

229. Xu, M., Zhang, L., Liu, G., Jiang, N., Zhou, W., \& Zhang, Y. (2019). Pathological Changes in Alzheimer's Disease Analyzed Using Induced Pluripotent Stem Cell-Derived Human 
Microglia-Like Cells. Journal of Alzheimer's Disease, 67(1), 357-368. https://doi.org/10.3233/JAD-180722

230. Claes, C., Daele, J. V. D., Boon, R., Schouteden, S., Colombo, A., Monasor, L. S., ... Verfaillie, C. M. (2019). Human stem cell-derived monocytes and microglia-like cells reveal impaired amyloid plaque clearance upon heterozygous or homozygous loss of TREM2. Alzheimer's \& Dementia, 15(3), 453-464. https://doi. org/10.1016/j.jalz.2018.09.006

231. Alić, I., Goh, P. A., Murray, A., Portelius, E., Gkanatsiou, E., Gough, G., ... Nižetić, D. (2020). Patient-specific Alzheimer-like pathology in trisomy 21 cerebral organoids reveals BACE2 as a gene dose-sensitive AD suppressor in human brain. Molecular Psychiatry, 1-23. https://doi.org/10.1038/s41380-020-0806-5

232. Gonzalez, C., Armijo, E., Bravo-Alegria, J., Becerra-Calixto, A., Mays, C. E., \& Soto, C. (2018). Modeling amyloid beta and tau pathology in human cerebral organoids. Molecular psychiatry, 23(12), 2363-2374. https://doi.org/10.1038/s41380-018-0229-8

233. Pavoni, S., Jarray, R., Nassor, F., Guyot, A.-C., Cottin, S., Rontard, J., ... Yates, F. (2018). Small-molecule induction of A $\beta-42$ peptide production in human cerebral organoids to model Alzheimer's disease associated phenotypes. PLoS ONE, 13(12). https:// doi.org/10.1371/journal.pone.0209150

234. Raja, W. K., Mungenast, A. E., Lin, Y.-T., Ko, T., Abdurrob, F., Seo, J., \& Tsai, L.-H. (2016). Self-Organizing 3D Human Neural Tissue Derived from Induced Pluripotent Stem Cells Recapitulate Alzheimer's Disease Phenotypes. PLOS ONE, 11(9), e0161969. https://doi.org/10.1371/journal.pone.0161969

235. Park, J.-C., Jang, S.-Y., Lee, D., Lee, J., Kang, U., Chang, H., ... Mook-Jung, I. (2021). A logical network-based drug-screening platform for Alzheimer's disease representing pathological features of human brain organoids. Nature Communications, 12(1), 280. https://doi.org/10.1038/s41467-020-20440-5

236. Hernández, D., Rooney, L. A., Daniszewski, M., Gulluyan, L., Liang, H. H., Cook, A. L., ... Pébay, A. (2021). Culture Variabilities of Human iPSC-Derived Cerebral Organoids Are a Major Issue for the Modelling of Phenotypes Observed in Alzheimer's Disease. Stem Cell Reviews and Reports. https://doi.org/10.1007/ s12015-021-10147-5

237. Choi, S. H., Kim, Y. H., Hebisch, M., Sliwinski, C., Lee, S., D'Avanzo, C., ... Kim, D. Y. (2014). A three-dimensional human neural cell culture model of Alzheimer's disease. Nature, 515(7526), 274-278. https://doi.org/10.1038/nature13800

238. Ormel, P. R., Sá, R. V. de, Bodegraven, E. J. van, Karst, H., Harschnitz, O., Sneeboer, M. A. M., ... Pasterkamp, R. J. (2018). Microglia innately develop within cerebral organoids. Nature Communications, 9(1), 1-14. https://doi.org/10.1038/ s41467-018-06684-2

239. Quadrato, G., Nguyen, T., Macosko, E. Z., Sherwood, J. L., Min Yang, S., Berger, D. R., ... Arlotta, P. (2017). Cell diversity and network dynamics in photosensitive human brain organoids. Nature, 545(7652), 48-53. https://doi.org/10.1038/nature22047

240. Sloan, S. A., Darmanis, S., Huber, N., Khan, T. A., Birey, F., Caneda, C., ... Paşca, S. P. (2017). Human Astrocyte Maturation Captured in 3D Cerebral Cortical Spheroids Derived from Pluripotent Stem Cells. Neuron, 95(4), 779-790.e6. https://doi. org/10.1016/j.neuron.2017.07.035

241. Grebenyuk, S., \& Ranga, A. (2019). Engineering Organoid Vascularization. Frontiers in Bioengineering and Biotechnology, 7. https://doi.org/10.3389/fbioe.2019.00039

242. Camp, J. G., Badsha, F., Florio, M., Kanton, S., Gerber, T., WilschBräuninger, M., ... Treutlein, B. (2015). Human cerebral organoids recapitulate gene expression programs of fetal neocortex development. Proceedings of the National Academy of Sciences, 112(51), 15672-15677. https://doi.org/10.1073/pnas.1520760112
243. Shi, Y., Kirwan, P., Smith, J., MacLean, G., Orkin, S. H., \& Livesey, F. J. (2012). A Human Stem Cell Model of Early Alzheimer's Disease Pathology in Down Syndrome. Science Translational Medicine, 4(124), 124ra29-124ra29. https://doi.org/10.1126/scitranslm ed.3003771

244. Woodruff, G., Young, J. E., Martinez, F. J., Buen, F., Gore, A., Kinaga, J., ... Goldstein, L. S. B. (2013). The Presenilin-1 $\Delta$ E9 Mutation Results in Reduced $\gamma$-Secretase Activity, but Not Total Loss of PS1 Function, in Isogenic Human Stem Cells. Cell Reports, 5(4), 974-985. https://doi.org/10.1016/j.celrep.2013.10.018

245. Liu, Q., Waltz, S., Woodruff, G., Ouyang, J., Israel, M. A., Herrera, C., ... Yuan, S. H. (2014). Effect of potent $\gamma$-secretase modulator in human neurons derived from multiple presenilin 1-induced pluripotent stem cell mutant carriers. JAMA neurology, 71(12), 1481-1489. https://doi.org/10.1001/jamaneurol.2014.2482

246. Maloney, J. A., Bainbridge, T., Gustafson, A., Zhang, S., Kyauk, R., Steiner, P., ... Atwal, J. K. (2014). Molecular mechanisms of Alzheimer disease protection by the A673T allele of amyloid precursor protein. The Journal of Biological Chemistry, 289(45), 30990-31000. https://doi.org/10.1074/jbc.M114.589069

247. Dashinimaev, E. B., Artyuhov, A. S., Bolshakov, A. P., Vorotelyak, E. A., \& Vasiliev, A. V. (2017). Neurons derived from induced pluripotent stem cells of patients with down syndrome reproduce early stages of alzheimer's disease type pathology in vitro. Journal of Alzheimer's disease: JAD, 56(2), 835-847. https://doi.org/10.3233/JAD-160945

248. Moreno, C. L., Della Guardia, L., Shnyder, V., Ortiz-Virumbrales, M., Kruglikov, I., Zhang, B., ... Gandy, S. (2018). iPSCderived familial Alzheimer's PSEN2 N141I cholinergic neurons exhibit mutation-dependent molecular pathology corrected by insulin signaling. Molecular Neurodegeneration, 13(1), 33. https://doi.org/10.1186/s13024-018-0265-5

249. Ovchinnikov, D. A., Korn, O., Virshup, I., Wells, C. A., \& Wolvetang, E. J. (2018). The impact of app on alzheimer-like pathogenesis and gene expression in down syndrome iPSC-derived neurons. Stem Cell Reports, 11(1), 32-42. https://doi.org/10. 1016/j.stemcr.2018.05.004

250. Robbins, J. P., Perfect, L., Ribe, E. M., Maresca, M., DanglaValls, A., Foster, E. M., ... Lovestone, S. (2018). Clusterin Is Required for $\beta$-Amyloid Toxicity in Human iPSC-Derived Neurons. Frontiers in Neuroscience, 12, 504. https://doi.org/10.3389/ fnins.2018.00504

251. Wang, C., Najm, R., Xu, Q., Jeong, D.-E., Walker, D., Balestra, M. E., ... Huang, Y. (2018). Gain of toxic apolipoprotein E4 effects in human iPSC-derived neurons is ameliorated by a smallmolecule structure corrector. Nature Medicine, 24(5), 647-657. https://doi.org/10.1038/s41591-018-0004-z

252. Wezyk, M., Szybinska, A., Wojsiat, J., Szczerba, M., Day, K., Ronnholm, H., ... Zekanowski, C. (2018). Overactive BRCA1 affects presenilin 1 in induced pluripotent stem cell-derived neurons in Alzheimer's disease. Journal of Alzheimer's disease: JAD, 62(1), 175-202. https://doi.org/10.3233/JAD-170830

253. Chang, K.-H., Lee-Chen, G.-J., Huang, C.-C., Lin, J.-L., Chen, Y.-J., Wei, P.-C., ... Chen, C.-M. (2019). Modeling Alzheimer's disease by induced pluripotent stem cells carrying APP D678H mutation. Molecular Neurobiology, 56(6), 3972-3983. https:// doi.org/10.1007/s12035-018-1336-x

254. Wadhwani, A. R., Affaneh, A., Van Gulden, S., \& Kessler, J. A. (2019). Neuronal apolipoprotein E4 increases cell death and phosphorylated tau release in alzheimer disease. Annals of Neurology, 85(5), 726-739. https://doi.org/10.1002/ana.25455

255. Arber, C., Toombs, J., Lovejoy, C., Ryan, N. S., Paterson, R. W., Willumsen, N., ... Wray, S. (2020). Familial Alzheimer's disease patient-derived neurons reveal distinct mutation-specific effects 
on amyloid beta. Molecular Psychiatry, 25(11), 2919-2931. https://doi.org/10.1038/s41380-019-0410-8

256. Martins, S., Müller-Schiffmann, A., Erichsen, L., Bohndorf, M., Wruck, W., Sleegers, K., ... Adjaye, J. (2020). IPSC-derived neuronal cultures carrying the Alzheimer's disease associated TREM2 R47H variant enables the construction of an A $\beta$-induced gene regulatory network. International Journal of Molecular Sciences, 21(12), 4516. https://doi.org/10.3390/ijms21124516

257. Konttinen, H., Cabral-da-Silva, M., \& e C., Ohtonen, S., Wojciechowski, S., Shakirzyanova, A., Caligola, S., ... Malm,
T. . (2019). PSEN1 $\triangle E 9$, APPswe, and APOE4 Confer Disparate Phenotypes in Human iPSC-Derived Microglia. Stem Cell Reports, 13(4), 669-683. https://doi.org/10.1016/j.stemcr.2019. 08.004

Publisher's Note Springer Nature remains neutral with regard to jurisdictional claims in published maps and institutional affiliations. 